\title{
A first generation African community grappling with urbanisation: the views of Platfontein's San on water and sanitation service delivery
}

\author{
JWN TEMPELHOFF ${ }^{1}$ \\ Watching the cloud grow, we observe that \\ nothing is quite the same from one moment to \\ the next... Tim Ingold ${ }^{2}$
}

\begin{abstract}
Since their relocation in 2004 to Platfontein near Kimberley in South Africa's Northern Cape Province, members of the !Xun and Khwe San, originally from the northern parts of Namibia and southern Angola, became a first generation African community grappling with urbanisation in a rapidly modernising South Africa. The Platfontein area, a number of farms with a settlement housing complex accommodating about 7000 people, is currently an emergent urban area in which residents have the opportunity to lead urban lives. However, the local water supply and sanitation infrastructure is in a bad state. People reside in early RDP houses, which since being handed over by the Department of Housing have not all been provided with proper water, sanitation and electricity.

In the article attention is given to the perceptions of the San community of Platfontein on their prospects for the future under current conditions. The focus is on local water and sanitation service delivery provided by the Sol Plaatje Local Municipality. In many respects their views reflect the complex cultural adjustments necessary to live in an urban environment. Water supply and sanitation are services taken for granted in a modern urban setting. The fact that the San community is subject to considerable frustration about poor service delivery in these important services is a root cause of their discontent with the realities of life in an urban environment that does not live up to their expectations.
\end{abstract}

Keywords: Water and sanitation, service delivery, Northern Cape, Platfontein, San, !Xun and Khwe, Kimberley.

\section{Introduction}

The township of Platfontein, situated about $15 \mathrm{~km}$ southwest of Kimberley in South Africa's Northern Cape Province, is home to a San community currently grappling with the problem of adapting to urbanisation. What makes their situation exceptional is the fact that Platfontein's San residents are a first generation of Africans who previously resided as highly mobile people in small communities in some of the most isolated areas of southern Africa. Urbanisation in itself is not new. People have been living in urban environments in many parts of the world for more than five millennia. However, since the twentieth century there have been significant demographic changes taking place, especially on the African continent. For example, in Africa south of the Sahara, the estimated 1.1 billion people who by 2011 had

\footnotetext{
1 Research Niche for the Cultural Dynamics of Water (CuDyWat), School of Basic Sciences, NorthWest University, Vaal Triangle Campus, Vanderbijlpark Gauteng South Africa. Email: johann.tempelhoff@nwu.ac.za

Evolution and Social Life, Cambridge University Press, Cambridge, 1986, p. 134.
}

Td The Journal for Transdisciplinary Research in Southern Africa, 10(4) December 2014, Special edition: San dispute resolution, pp. 52-83. 
moved to cities were expected to increase to 2.4 billion by $2050 .{ }^{3}$ Of South Africa's more than 50 million residents, $59.3 \%$ were living in urban areas in 2005; this may rise to $70 \%$ of the total population of the country by $2050 .{ }^{4}$

Many South Africans who have moved to formal residential urban areas since 1994, take it for granted that urbanisation implies that they will have access to a potable water supply, sanitation and proper storm water drainage infrastructure. Since the seventeenth century the country's colonial history has linked urban South Africa to a tradition of urban water governance dating back to classical times in Western Europe. After the British assumed control of the Cape Colony in 1806 a system of municipal governance was introduced that reflected certain prevalent modern trends. By the 1800s the Industrial Revolution had made Britain's political leaders and civil servants aware of the need for well-managed potable water purification plants and proper wastewater treatment works. In the first half of the century London, one of the largest cities in the world at the time, intermittently reeled under severe outbreaks of contagious waterborne diseases such as cholera, typhus and diarrhoea. ${ }^{5}$ Consequently, the British made a significant breakthrough in what has been termed the "sanitation revolution" - ensuring that urban water and sanitation systems were well managed. The outcome was that mortality rates dropped significantly in urban areas. ${ }^{6}$ Similar measures were soon introduced in Western Europe and North America, setting a global example. ${ }^{7}$ In South Africa too, proper sanitation infrastructure became a hallmark of modern urban areas. ${ }^{8}$ By the twentieth century the country's predominantly white minority inhabited urban areas that compared well with the best-managed water and sanitation urban systems in the world.

After 1994, the new government of national unity committed itself to working in the interest of previously disadvantaged communities and providing sufficient urban housing in postapartheid South Africa. In the process of embarking on a monumental urban development strategy, proper municipal water and sanitation service delivery frequently came under the public spotlight for all the wrong reasons.

In the discussion to follow attention is given to the San people of Platfontein who, since 2004 when they were relocated from Schmidtsdrift, have been subject to an intense phase of

3 Population Reference Bureau, (PRB), World Population Data Sheet 2013, Accessed 31 July 2014, http://goo.gl/yJOoN1.

4 Department of Economic and Social Affairs (DESA): Population Division, World Urbanization Prospects: The 2011 Revision, United Nations, New York, 2012, p. 127.

5 S Halliday, The Great Stink of London: Sir Joseph Bazalgate and the Cleansing of the Victorian Metropolis, The History Press, Brimscombe Port, Stroud, 2013.

6 D Sedlack, Water 4.0: The Past, Present and Future of the World's Most Vital Resource, Yale University Press, New Haven, 2014, pp. 25-40.

7 S Solomon, Water: The Epic Struggle for Wealth, Power and Civilization, Harper-Collins eBooks, New York, 2009, pp. 75-6; C Smith, City Water, City Life: Water and the Infrastructure of Ideas in Urbanising Philadelphia, Boston and Chicago, University of Chicago Press, Ltd., London, 2013, Locations 110-133.

8 H Mäki, Water, Sanitation and Health: The Development of the Environmental Services in Sour South African Cities, 1840-1920, Kehrä Media Inc. Tampere, 2008, pp. 15-29; GFJ King, 'Skarreling': A Socio-Environmental History of Household Waste in South Africa (MA, Stellenbosch University, 2014, pp. 14-19. 
urbanisation. In particular, the focus is on their perceptions of water and sanitation service delivery. They live on the fringe of an urban society and are part of it, and yet they still feel marginalised. Listening to what these people say about water and sanitation does drive home a message. There is an expectation that water and sanitation should be similar to that enjoyed by people in neighbouring suburban residential areas and yet they are deprived of these basic urban services. Under these circumstances they experience problems forging a new cultural lifestyle.
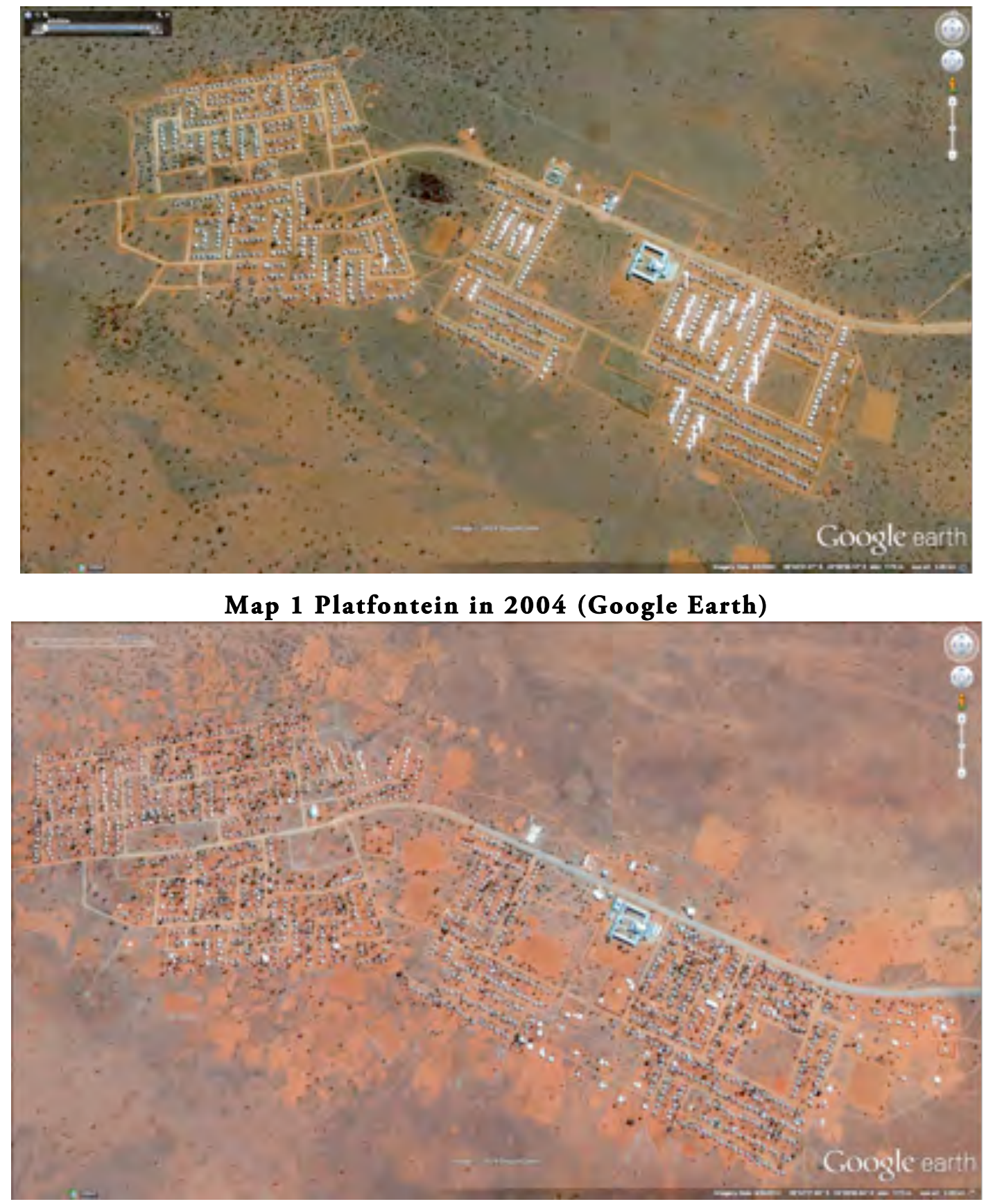

Map 2 Platfontein ten years later, in 2014. Informal structures have increased on the edges of western, southern and eastern part of the settlement (Google Earth)

\section{A complex community}

The San community of Platfontein forms part of a sub-continental regional society of former hunting, foraging, and pastoral Africans who have been subjected to intense waves of 
complex socio-economic and political change. Residents are respectively members of the !Xun and Khwe ethnic communities. They formerly resided in the south and south-eastern parts of Angola and Northern Namibia. ${ }^{9}$ Their cultural dynamics since the 1960s have been shaped on the periphery of the African decolonisation process as it played itself out on the southern sub-continent. On numerous occasions they found themselves in the epicentre of liberation wars between colonial powers and African nationalists. First, they were used as flechas (auxiliaries) by the Portuguese to prevent the nationalist União Nacional para a Indepêndencia Total de Angola (Unita) from undermining the stability of colonial Angola. ${ }^{10}$ Then, in 1975, a socialist revolution in Lisbon toppled the old regime in Portugal and two of its colonies in southern Africa, Angola and Mozambique, became independent states. Hardly had the new government in Angola taken control before the former South African Defence Force (SADF) in Namibia recruited the San to help in the white South African government's fight against the liberation forces of the South West African Peoples' Organisation (SWAPO) and later their Cuban allies who posed a threat to the former colony of German South-West Africa, which had been a protectorate of South Africa after World War I (19141918). ${ }^{11}$

During this period of upheaval, today's residents of Platfontein lived on the fringes of mainstream black rural village communities in the Caprivi, where they formed nuclear family groups. They led a highly mobile life. These once-isolated communities unwittingly became part of an on-going war that only drew to a conclusion in 1990 with the formation of an independent Namibia. Yet, even then there was little solace for them. If they remained in Namibia the chances were good that they would be subjected to persecution by the new SWAPO government. Consequently, a community of almost 4000 people were resettled by the SADF at Schmidtsdrift, near Kimberley in the Northern Cape Province, at the time when South Africans started negotiating a new multiracial democracy in the early 1990s. ${ }^{12}$

The advent of the new South Africa in 1994 was accompanied by a comprehensive political, social and economic transition. In the rural areas of the country communities that had earlier been forced off the land as a result of apartheid policies were allowed to reclaim the areas where they had previously lived. This was part of the new ANC government's comprehensive restitution programme. The land on which the San were living at Schmidtsdrift formed part of the ancestral lands of ethnic Tswana, Bathlapin and a group of Griqua people. The claim to the land by these groups was approved and the San of Schmidtsdrift had to be relocated. ${ }^{13}$ They were scheduled for relocation to an area not far from the city of Kimberley.

The preliminary process of urbanisation of the San began in a dusty tented village at Schmidtsdrift in 1990 and this re-location created a significant sense of uncertainty among them. The community had lost its right to live on the land. They now had to face ethnic

$9 \quad$ TN den Hertog, "Diversity behind Constructed Unity: The Resettlement Process of the !Xun and the Khwe Communities in South Africa”, Journal of Contemporary African Studies, 31(3), 2013, p. 349.

Ibid., p. 349.

$11 \quad$ Ibid., pp. 349-350.

12 RK Hitchcock, "Refugees, Resettlement, and Land and Resource Conflicts: The Politics of Identity among !Xun and Khwe San in Northeastern Namibia”, African Monographs, 33(2), June 2012, p. 86. 
merging which they felt would soon lead to their people becoming extinct. ${ }^{14}$ According to Major Charles Hallett, an expert on the community:

The Bushmen fear a swallowing up of their culture and their values when the 2000 young people of the Schmidtsdrift community reach Kimberley in the next few months.

They want somewhere they can belong. ${ }^{15}$

In 1999, President Nelson Mandela granted the San community of Schmidtsdrift 13000ha of farming land near Kimberley, which included the farm Platfontein on which they were scheduled to reside. ${ }^{16}$ In addition, the community received 900 individual Reconstruction and Development (RDP) housing grants to the value of R15 000 each that enabled each family to purchase a home. ${ }^{17}$ In August 2000, the SABC radio station X-K FM started transmissions to the community at Schmidtsdrift in their respective vernacular languages, as well as in Afrikaans. ${ }^{18}$ This service followed them to Platfontein. Despite the gestures of acceptance by the South African government, the San continued to feel marginalised. It was as if they remained on the fringes of mainstream society - much the same as they had been in Angola. In 2000, a community member commented to the media:

\section{It seems our nation is not the same as the blacks. They have their own government and} they don't care about us. ${ }^{19}$

This was despite the fact that the !Xun and Khwe were amongst the first communities in the country to receive land in terms of the new government's land reform programme. Their sense of marginalisation was not unfounded, because more than four years after the promise of land had been made, little had come of the plans to provide the community with proper housing. ${ }^{20}$

In April 2003, the media reported on the dire circumstances of the San who were still at Schmidtsdrift, living in tattered tents under dismal circumstances. Some were even living in makeshift shelters on the banks of the Orange River, while others contemplated simply moving away. ${ }^{21}$

The then Northern Cape Province premier, Manny Dipico, promised the community that they would be relocated..$^{22}$ At the same time the Northern Cape Provincial Housing Department announced that 500 houses had been budgeted for and these would be available

Anon., San Fear Land Reform Spells Extinction, IOL, 8 July 1999, Accessed 7 September 2014, http://goo.g1/kw8TFK

Ibid.

Smith, Former San Soldiers still Waiting for Houses.

B Weidlich, San Face Lifestyle Threat, in IOL, 15 October 2007, Accessed 7 September 2014, http://goo.gl/tVnPgL

Anon., Northern Cape Gets San Language Radio, in IOL, 19 August 2000, Accessed 7 September 2014, http://goo.gl/x5e0Fw

A Seccombe, San Trackers Lay Claim to Drakensberg Land, in IOL 13 August 2000, Accessed 7 September 2014, http://goo.g1/rgSkk9

Smith, Former San Soldiers still Waiting for Houses.

Ibid.

Ibid. 
for occupation by the end of $2003 .{ }^{23}$ In the interim a group of about 400 community members moved to Platfontein, where they lived in workers' houses on what had formerly been white-owned farms. Instead of becoming part of an existing urban community, they had to create urban spaces in what was scheduled to become a typical South African township.

A few of the San put up shacks, but complained that they were not used to living in shanties. ${ }^{24}$ Some community members had grave reservations about the empty promises made by the government. Mr Rennie Mishe, a member of the Community Property Association (CPA), told the media it seemed as if nothing was really happening at Platfontein where the community was scheduled to be resettled. At the time not a single one of the promised 1000 houses had been built. ${ }^{25}$ In January 2004, amid a hive of construction activities, the !Xunkhwesa Combined School opened its doors to 1200 pupils and 33 teachers. Up to that time the community's children had attended school in a makeshift town of tents at the former Schmidtsdrift. ${ }^{26}$ Later the same year the remainder of the community had also been relocated to Platfontein.

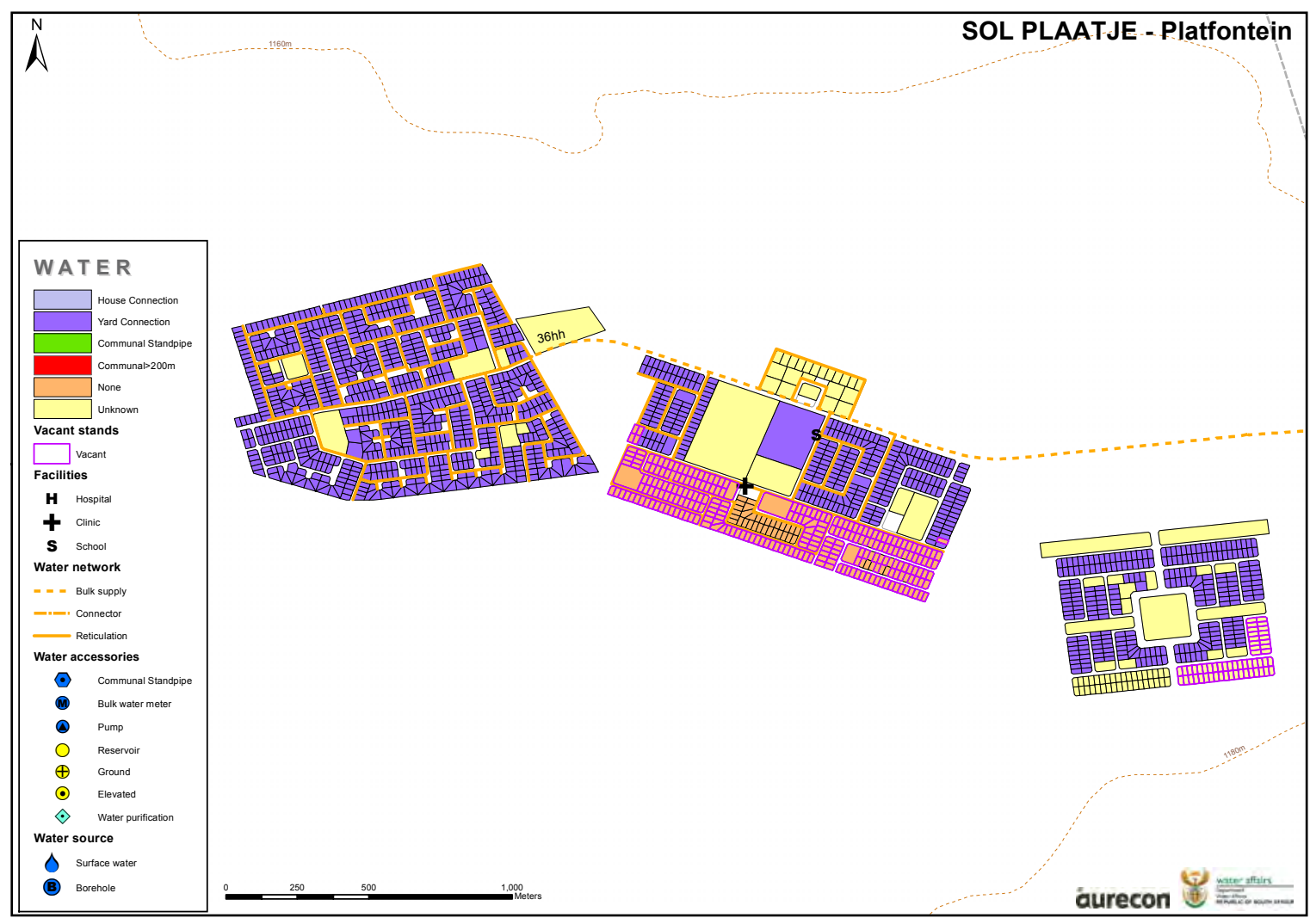

Map 3 With the exception of the middle block the greater part of Platfontein by 2014 at least had standpipes for potable water supplies. (DWS, Kimberley, 2014)

\footnotetext{
23 Ibid.

24 Ibid.

25 Ibid.

26 M Smith, Long Wait for !Xun and !Khwe Homecoming Ends, in IOL, 20 January 2004, Accessed 7 September 2014, http://goo.g1/no9Gcs
} 
The housing project was executed in a short period of time. The structures were built on the pattern of the first RDP houses, notable for their spartan and rudimentary style. In terms of water supply and sanitation residents were provided with standpipes for potable water and ventilated improved pit (VIP) toilets. In the Northern Cape, geographically the largest province of South Africa with the lowest population (1.1 million in 2011), municipalities provided VIP and urine diversion sanitation (UDS) systems because of financial constraints and water scarcity in the province. In most communities the dry sanitation systems did not work well, partially because of inferior workmanship in their construction and residents who were not properly educated on the use of the facilities. ${ }^{27}$

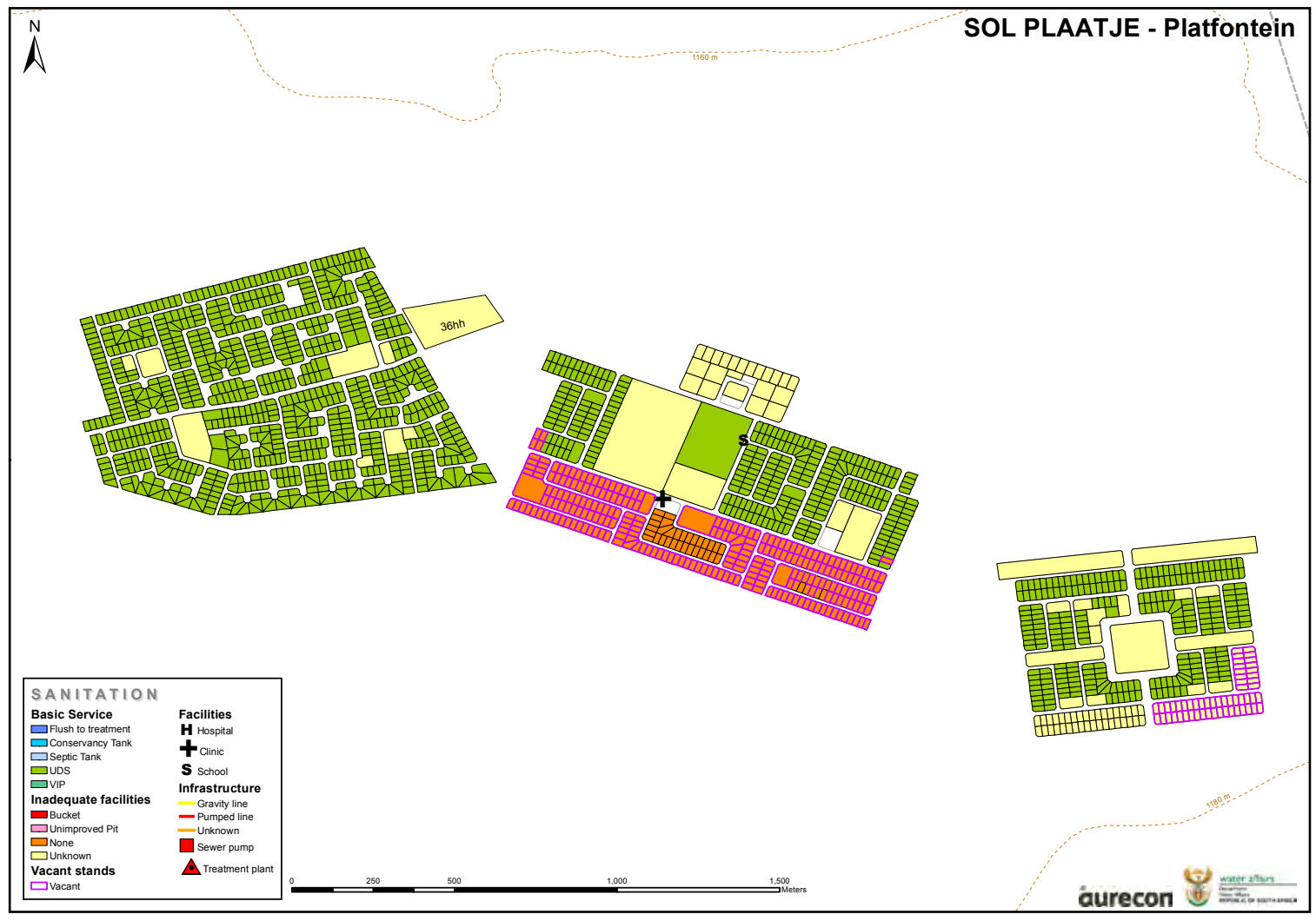

Map 4 In 2004 houses were fitted with ventilated improved pit latrines (VIPs). The southernmost part of the middle block and the far eastern section of the township either had unimproved pit latrines with some stands having no facilities at all (DWS, Kimberley, 2014)

\section{Historical consciousness of their association with water}

The San people of southern Africa traditionally have strong ties with water. The earliest foreign travellers in the sub-continent noted how skilful the San and Khoi were at procuring water under adverse arid conditions. ${ }^{28}$ They astounded friend and foe alike with their ability

27. Department of Human Settlements, Ministerial Task Team Report. Review, Investigation and Evaluation of the National Sanitation Programme - towards Continuous Improvement (July 2012), pp. 310-313. 
to thrive under adverse circumstances of persecution, drought and famine. ${ }^{29} \mathrm{Up}$ to the present, in the regions in which they reside, water typically remains at a premium. Climatic conditions in the western parts of the sub-continent tend to vary between semi- and extremely arid (less than $25 \mathrm{~mm}$ per annum) and form part of the $65 \%$ of the country's land surface that receives less than $500 \mathrm{~mm}$ of rain every year. ${ }^{30}$

South Africa's average rainfall is a meagre $450 \mathrm{~mm}$ per annum, which is well below the world annual average of $860 \mathrm{~mm} .^{31}$

Platfontein is also situated in a relatively arid part of the country. The communal land borders the Wildebeestkuil rock art heritage site, which tells the story of the Platfontein residents' Late Stone Age ancestors who were residents in the region, where a series of pans formed wetlands around an imposing koppie in the years of good rains.

From the historical record we also know that traditionally the San, as was also the case with their related Khoi neighbours, lived a mobile life closely associated with the seasonal availability of water supplies. The Khoisan, as they have been described collectively, traditionally moved around in search of food. Dwellings and sites of residence were thus always temporary. ${ }^{32}$ They tended to have different places of residence in the rainy and the dry seasons. In the case of the Khoisan of the Okavango-Zambezi region, the Tannekwe San lived in the marshlands of the Okavango basin. Here they had small villages with palisades, similar to those of the local Bantu-speaking peoples. ${ }^{33}$ When the rains started in the area, living conditions were difficult and they moved away. Village settlements were then relocated to the edge of the surrounding plains where their hunting grounds were situated. ${ }^{34}$

The Hukwe people at Lake Ngami followed a similar lifestyle. In the rainy season they lived in a relatively compact village settlement. Once the dry season set in they split up into smaller groups and spread further afield and survived by hunting and gathering. ${ }^{35}$ For the rest, according to Schapera, the Khoisan led a nomadic life. Those who were accustomed to living in mountainous regions found caves and rock shelters in which to live in the southern and

and Blackett, London, 1856, pp. 319-20; T Baines, Journal of Residence in Africa 1842-1853, volume 1, 1842-1849, Edited by RF Kennedy, The Van Riebeeck Society, Cape Town, 1961, pp. 188-189. (Entry: 26 September 1849); CP Thunberg, Travels at the Cape of Good Hope, 1772-1775, Original c. 1795. Edited by VS Forbes. Translation from the Swedish revised by J. \& I. Rudner; contributions to the foreword by I. Rudner \& J. Rourke, Van Riebeeck Society Cape Town, 1986, pp. 57, 248, 251, 313.

Hitchcock, "Refugees, Resettlement, and Land and Resource Conflicts", pp. 77-78.

A(D) Van Zyl, South African Weather and Atmospheric Phenomena, Briza Publications, Pretoria, 2003, p. 36.

Department of Water Affairs and Forestry (DWAF), National Water Resource Strategy (NWRS), 1st edition, DWAF, Pretoria, 2004; K Rowntree, "Geography of Drainage Basins: Hydrology, Geomorphology, and Ecosystems management", in R Fox, and E Rowntree (eds.), The Geography of South Africa in a Changing World, Oxford University Press, Cape Town, 2000, pp. 394.

I Schapera, The Khoisan People of South Africa: Bushmen and Hottentots, Routledge \& Kegan Paul, London, 1960, p. 86.

Ibid.

Ibid.

Ibid.

Td, 10(4), December 2014, pp. 52-83. 
eastern parts of southern Africa. ${ }^{36}$ As recently as the early twentieth century, in the latter part of the dry season, the Namib San still sheltered in caves and overhanging rock shelters in the mountainous regions of Great Namaqualand. ${ }^{37}$ Wherever they stayed for more than a few days, the San women would make crude bush huts, as a rule at sites relatively close to watering places. ${ }^{38}$ These would form part of their hunting areas.

The descendants of these people are currently a first generation of urbanised San located at the township of Platfontein. They have had to contend with the trials and tribulations of becoming part of a rapidly urbanising South African society. Apart from an increasing shortfall in sufficient housing, the water-related infrastructure of the community is below standard. In the discussion that follows, attention is given to how this community experiences life at Platfontein in terms of water supply, sanitation and storm-water facilities, and to the community's perceptions of the problems experienced in this regard since 2004.

\section{Historical recollections of water}

In discussions with members of the community at the time of a fieldwork visit to Platfontein in August 2014, it was emphasised that for them as indigenous people water is an important resource. In essence, water represents life: ${ }^{39}$ the water they drank in former times gave them energy. ${ }^{40}$ They knew how to manage water when there was little available. ${ }^{41}$ They were innovative and able to store water and thrived under conditions where outsiders would succumb to thirst. They spoke of how members of the community, formerly resident in parts of Namibia and Angola, were able to secure water supplies from the bark of trees, rivers and natural and man-made lakes (shonas) ${ }^{42}$ and how they now (in 2014) find themselves in the unenviable position of having to rely on a municipal authority ${ }^{43}$ for a water supply that some community members consider to be of dubious quality. ${ }^{44}$

At the time of the interviews the residents, part of the older generation coming from Angola, had fond recollections of the water they drank that came from the wells they had dug personally. ${ }^{45}$ Others who originally lived in Namibia remembered how they drank water from dams. They also pointed out that when they were transferred to Schmidtsdrift, at the time Namibia became independent, they made the transition to drinking water from the river. ${ }^{46}$ River water, for many of the older people, was not foreign. They acknowledged drinking

\footnotetext{
36

Ibid.

Ibid., pp. 86-7.

Ibid., p. 87.

TOA20140815 !Xun and Khwe CPA, DSD, Platfontein: N.

TOA20140815 Women, NGK, Platfontein: RN.

W le Roux and A White (eds), Voices of the San: Living in Southern Africa Today, Kwela Books, Cape Town, 2004, pp. 90-92.

TOA20140815 !Xun and Khwe CPA, DSD, Platfontein: NK; FMM.

Ibid.

TOA20140816 Khwe CPA, DSD, Platfontein: PC.

TOA20140815 Women, NGK, Platfontein: AC.

TOA20140815 Women, NGK, Platfontein: KM.
} 
from streams in former times, but their main drinking water source was from wells. ${ }^{47}$ There were also times when they had to drink muddy and dirty water in the bush, but that was only under exceptional circumstances. ${ }^{48}$ One resident recollected how in Angola they had extracted good water from the river. ${ }^{49}$ Women of the !Xun frequently made reference to how they collected water in the areas where they came from. One explained:

When we were in Namibia we did not drink water that came from other people. We drank water from the dam. When we moved to Schmidtsdrift we drank water that came from the river. ${ }^{50}$

The water of the (Vaal) river at Schmidtsdrift is fondly remembered. ${ }^{51}$ However, according to disclosures by people outside the community, the community experienced hard times. ${ }^{52}$ Interestingly, they did not consider the SADF that cared for them and provided them with water at the time of the Bush War (or Border War, 1975-1990) as "outsiders". Instead, it seemed as if they considered themselves part of the Defence Force - an institution that seemed to care for its people and for everybody's water supply.

The leadership of the CPA lamented the fact that when the community took up residence at Platfontein, it was the first time that the San had to rely on "people from outside" to supply the community with water. ${ }^{53}$ They felt as if they were now only "users of water" because they were no longer responsible for its procurement. What concerned them was the fact that they did not even know where the water in their taps came from. ${ }^{54}$ One female respondent explained that it would be good if they could once again start digging wells to find water, as they had done in the "old days". However, the work, it was said, had to be done by the men in collaboration with the municipality. ${ }^{55}$ The water could then be stored in a dam. ${ }^{56} \mathrm{~A}$ community leader added a caveat, explaining that community members were unable to dig their own wells because they needed mechanical equipment such as that used by the municipality. ${ }^{57}$ It appeared as if the community as collective had already considered the problem and were of the opinion that a comprehensive water supply was necessary for Platfontein. Some people felt that when the time came for the local water infrastructure

TOA20140815 Women, NGK, Platfontein: RN.

TOA20140816 Khwe CPA, DSD, Platfontein: PC.

TOA20140815 Women, NGK, Platfontein: IP.

TOA20140815 Women, NGK, Platfontein: KM.

TOA20140815 Women, NGK, Platfontein: RN.

TOA20140711; H Smit, Director of the Southern African San Institute (SISA), Roodevallei, Pretoria; A Seccombe, San Trackers Lay Claim to Drakensberg Land; D Khecane, Anthrax Outbreak Sends Eight more to Hospital, in IOL, 7 January 2001, Accessed 7 September 2014, http://goo.gl/DCfnbH

TOA20140815 !Xun and Khwe CPA, DSD, Platfontein: N.

Ibid.

TOA20140815 Women, NGK, Platfontein: KM.

TOA20140815 Women, NGK, Platfontein: RN.

TOA20140815 !Xun and Khwe CPA, DSD, Platfontein: FMM

$T d, 10(4)$, December 2014, pp. 52-83. 
system to be upgraded, the community's unemployed men deserved to get jobs; they should even be responsible for the construction of the dam. ${ }^{58}$

\section{What people want}

The community of Platfontein is unanimous in their dissatisfaction about the current water and sanitation services. A senior leader of the community articulated the community's needs as follows:

We request waterborne toilets. We would also like showers or baths. We live under very unhygienic conditions. ${ }^{59}$

\section{Descriptions of water and sewage overflows at Platfontein}

At the time of discussions with individuals and groups there were complaints that the water flowing out of the tap in the morning was "dirty"; it had plant debris and a variety of solids. ${ }^{60}$ Others said that the water, when it came from the tap, had a white colour before settling down. They did not consider this to be part of a chlorine cleansing process, but instead expressed the opinion that the water caused them to become ill. ${ }^{61}$ The leadership of the CPA also expressed concerns about the water quality, stating that it was not always clean. ${ }^{62}$ According to one female participant, the water turned black after it had been boiled. It also appeared that there were "black things" and even hair in the water. ${ }^{63}$ Another said there were at times "small life forms" in the tap water, which made people fearful of drinking it. ${ }^{64}$

One leader explained that water users were uncertain whether the water was clean at all times. The colour of the water constantly changed. It was not always clear: sometimes impurities came out of the tap and at other times they would have the cleanest of crystal-clear drinking water. This leader frequently travelled to Kimberley and was aware that the water in Kimberley tasted different from the water at Platfontein. ${ }^{65}$

Naturally, rumour-mongering in the community was rife at the time of the research fieldwork conducted in mid-August 2014 because, as the community insisted, they were not fully aware of where their water came from. Some firmly believed Platfontein's water came from what they called the Gogga Pump, "all the dirty water coming from Kimberley" . seemed to be rife in the community. Of great concern was the fact that large amounts of raw sewage flowed onto their property from the dysfunctional Homevale wastewater treatment

TOA20140815 Women, NGK, Platfontein: KM.

TOA20140815 !Xun and Khwe CPA, DSD, Platfontein: FMM. Freely translated from the Afrikaans.

TOA20140815 !Xun and Khwe CPA, DSD, Platfontein: JD.

Informal discussion with social worker, Social Development office, Platfontein, 15 August 2014; TOA20140816 Khwe CPA, DSD, Platfontein: M Kapunda.

TOA20140815 !Xun and Khwe CPA, DSD, Platfontein: RM.

TOA20140815 Women, NGK, Platfontein: RN.

TOA20140816 Khwe CPA, DSD, Platfontein: PC.

TOA20140816 Khwe CPA, DSD, Platfontein: MJ.

TOA20140816 Khwe CPA, DSD, Platfontein: PC. 
works serving neighbouring townships. ${ }^{67}$ In discussions with members of the Platfontein community there were considerable complaints about the flooding of part of their property with sewage water emanating from the Gogga Pump (Homevale). ${ }^{68}$

In 2012, the Sol Plaatjie Local Municipality's main urban centre, Kimberley, had an estimated and burgeoning population of about 250000 residents. The city, one of the country's oldest formal urban areas, has for some time grappled with ageing water and sanitation infrastructure and rapid population growth. Following a pre-directive of the Department of Water Affairs in 2008, the municipal management placed a moratorium on all developments that required municipal infrastructure. A study on the municipality's infrastructure in 2009 suggested that it would cost at least R1.6 billion to eradicate the infrastructure backlog. The existing sources of municipal revenue were simply unable to carry these costs. In 2012, the government provided a Municipal Infrastructure Grant (MIG) to the local municipality to the tune of R34.5 million, which included an upgrade for the notorious Gogga Pump (Homevale) wastewater plant. ${ }^{69}$ By 2014, the plant was still not able to cope with large volumes of sewage. Moreover, the residents of Platfontein had not been beneficiaries of the infrastructure upgrade.

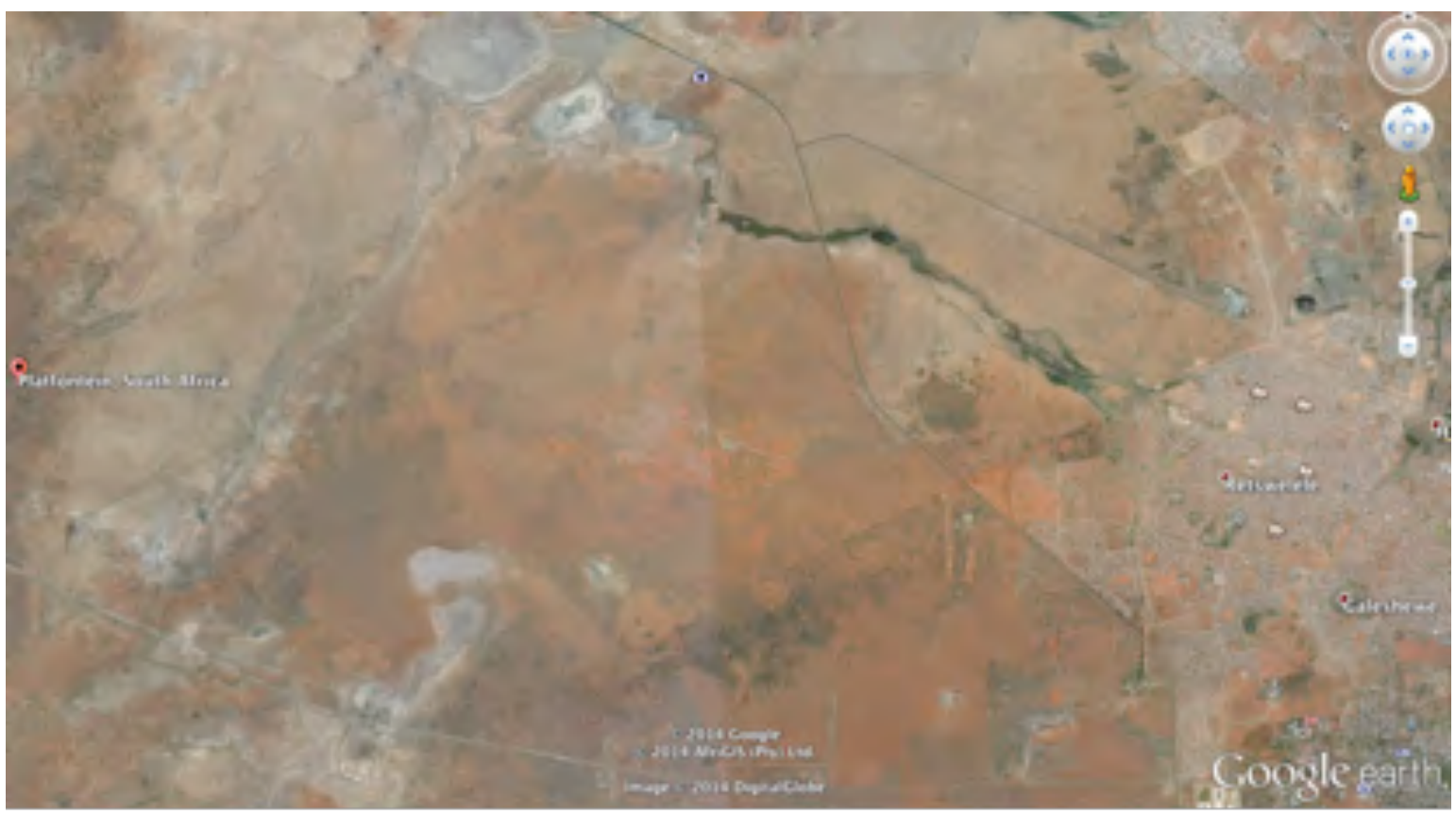

Map 5 Satellite image showing the dark line of raw sewage emanating from the Gogga Pump station - the largest wastewater treatment works in the Kimberley area. The highly dangerous spill is on the communal property of the San at Platfontein (Google Earth)

On 12 August 2014, community leaders met with officials of the Sol Plaatje Local Municipality and the provincial office of the Department of Water and Sanitation (DWS) to

\footnotetext{
67 See discussion below.

68 TOA20140815 !Xun and Khwe CPA, DSD, Platfontein: FMM.

69. Department of Human Settlements, Ministerial Task team Report. Review, Investigation and Evaluation of the National Sanitation Programme - towards Continuous Improvement (July 2012), pp. 329-333.
} 
visit the area of Platfontein where a significant amount of raw sewage flowed into an extensive wetland region and gravitated over a distance of several kilometres to the Wildebeestkuil rock art heritage site.

Earlier in the day a meeting was held between officials of the DWS with their counterparts from the Sol Plaatje Local Municipality. Under discussion was Homevale, the largest sewage pumping station in Kimberley. Officials of the DWS were concerned about the treatment works that had been dysfunctional for a number of months and the fact that large amounts of raw sewage flowed onto the land where the Platfontein community lived. The department's enforcement officials had earlier pinpointed the serious leakages and were aware that the community's children played in the area. There were also concerns about two local pans in the wetlands where the sewage spill accumulated in the winter months. The sites were the favourite grazing areas of local cattle and sheep. These conditions, according to them, posed a major threat to human health for the entire year. ${ }^{70}$

Leaders of the San community indicated that they had reported the spill to the local authority on numerous occasions. Nothing came of their requests for a positive response to the crisis. ${ }^{71}$ At the meeting officials of the local authority told the DWS officials there had been an agreement with the previous owner of Platfontein for the overflow from the wastewater treatment works to flow into the wetland. From the deliberations between the DWS and municipal officials, it was evident that the provincial water authority was not satisfied and wanted the problem to be addressed in an appropriate manner. ${ }^{72}$

In a discussion with the author, two days after the meeting, a senior community leader said the San did not want to be confrontational in their dealings with the authorities. Therefore the leadership had even discussed the option that the community should sell off part of the land in an effort to rid itself from the problem. ${ }^{73}$ It was apparent that this first generation of urban San people, in an effort to rid themselves of badly managed infrastructure, were even willing to compromise their right to own pristine land on the fringe of a high-density metropolitan area.

\section{Awareness of waterborne disease and hygiene}

Community members are acutely aware that water supplies are no longer as clean as they were in former times. Surface and groundwater supplies in many parts of southern Africa have been polluted. ${ }^{74}$ Often local residents refer indirectly to water as the cause of diseases they contracted; in many cases they placed the blame directly on water. One said, for

70

Department of Water and Sanitation, Northern Cape, Minutes of meeting on the Homevale Wastewater Treatment Plant: Technical Interventions, DWS, Regional Offices, Kimberley, 12 August, pp. 2-3.

Opinions expressed by community leaders who accompanied the researcher to the site of the sewage spill.

TOA20140815 !Xun and Khwe CPA, DSD, Platfontein: FMM.

Ibid.

TOA20140713 FMM, Roodevallei, Gauteng; Also see D Robbins, On the Bridge of Goodbye: The Story of South Africa's Discarded San Soldiers, Jonathan Ball Publishers, Johannesburg, 2007. See illustration and caption opposite p. 121. 
example, that people were getting sick because of the dirty water they were forced to drink. ${ }^{75}$ They described the water they consumed in former times as "pure". ${ }^{76}$ An elderly lady who spoke with considerable insight as a person who had raised not only her own children, but was now also responsible for raising her grandchildren, said it was evident that the local water supply was the primary cause of diseases in new-born babies. She claimed that infants frequently suffer from stomach-related diseases. ${ }^{77}$ Some community members said that the water they were exposed to caused high blood pressure. ${ }^{78}$ They were also of the opinion that the water was responsible for diabetes and tuberculosis. ${ }^{79}$ Another respondent said it caused asthma.$^{80}$ Diarrhoea was also given as one of the consequences of the dirty water. ${ }^{81}$

Leaders pinpointed the cause of disease as the sanitary conditions, explaining that the clinic staff would testify that many reports of sickness were directly related to sanitation and the state of the water in Platfontein. ${ }^{82}$ They also suggested that the authorities should give residents hygiene education in respect of water use. ${ }^{83}$ Awareness campaigns had been launched previously on water use but residents felt it was necessary to repeat this initiative. The local clinic did not always have sufficient and appropriate medicines for the treatment of people suffering from water-related diseases. According to a local community member the service was simply not up to standard. ${ }^{84} \mathrm{He}$ recollected how, in former times, the Red Cross would come to the community and communicate with them on health matters. The local authority had also sent officials who explained to them how to open windows for proper ventilation and how to boil water they considered suspect. ${ }^{85}$

\section{Problems with standpipe taps, hygiene and the need for hot water}

People complained about standpipe taps. The taps are outside and they have to go outdoors whenever they need water. ${ }^{86}$ Representatives of the CPA felt it would be better if the taps were located inside the dwellings. Residents could then control their own domestic consumption. ${ }^{87}$ It was said the problem with outdoor standpipes was that other people could

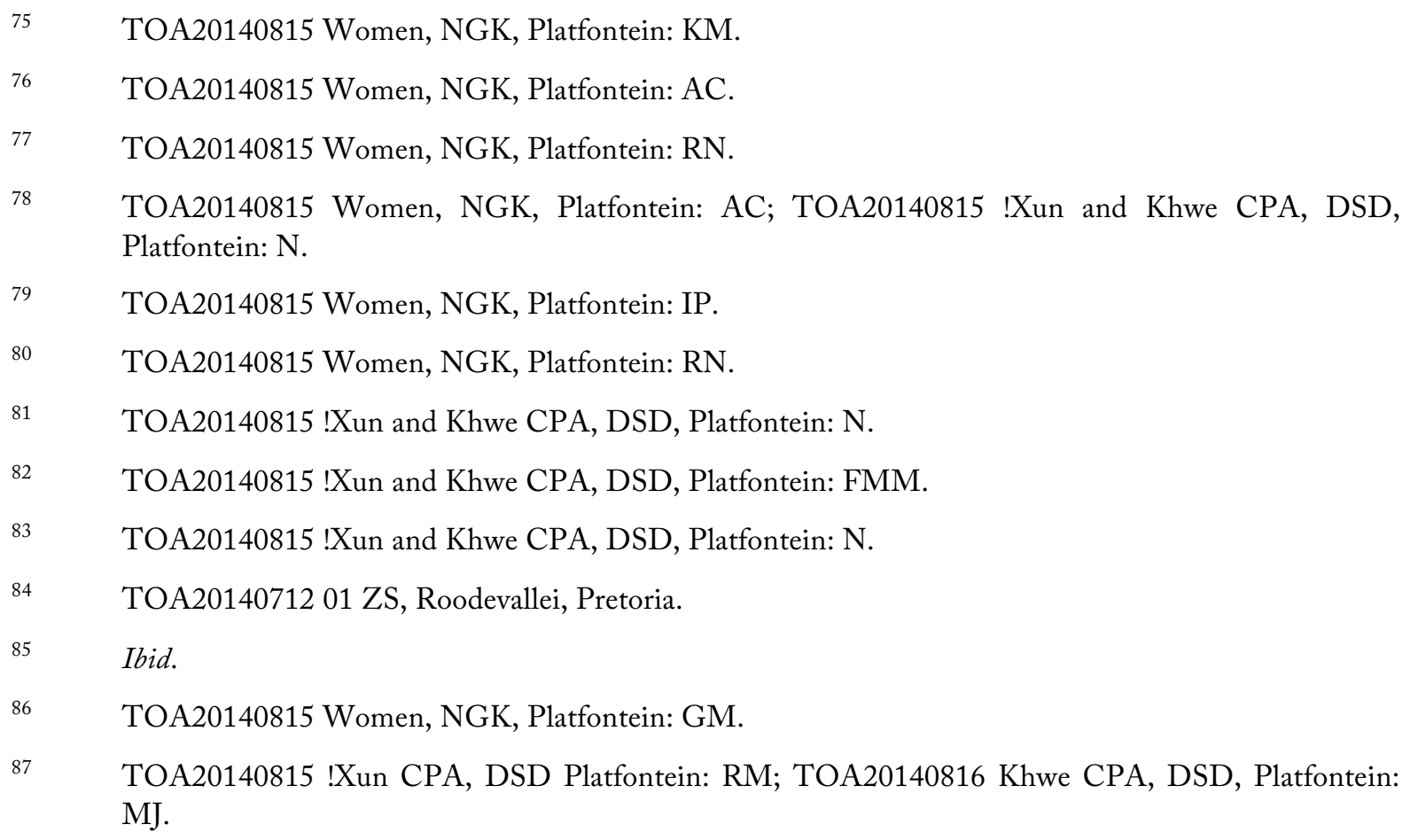


come during the night and take the residents' water. This leads to disputes with their neighbours who did not have their own water supplies. ${ }^{88}$ Those without tap water have to get supplies from close friends and well-disposed neighbours. It is evident that the San have become urbanites, living in the confines of their own homes and caring first and foremost for their own family members. A group of women interviewed complained that their houses were small and the water supplies were outdoors. They drew comparisons with facilities made available to residents in neighbouring communities; they also lived in small houses, but at least had water indoors. ${ }^{89}$

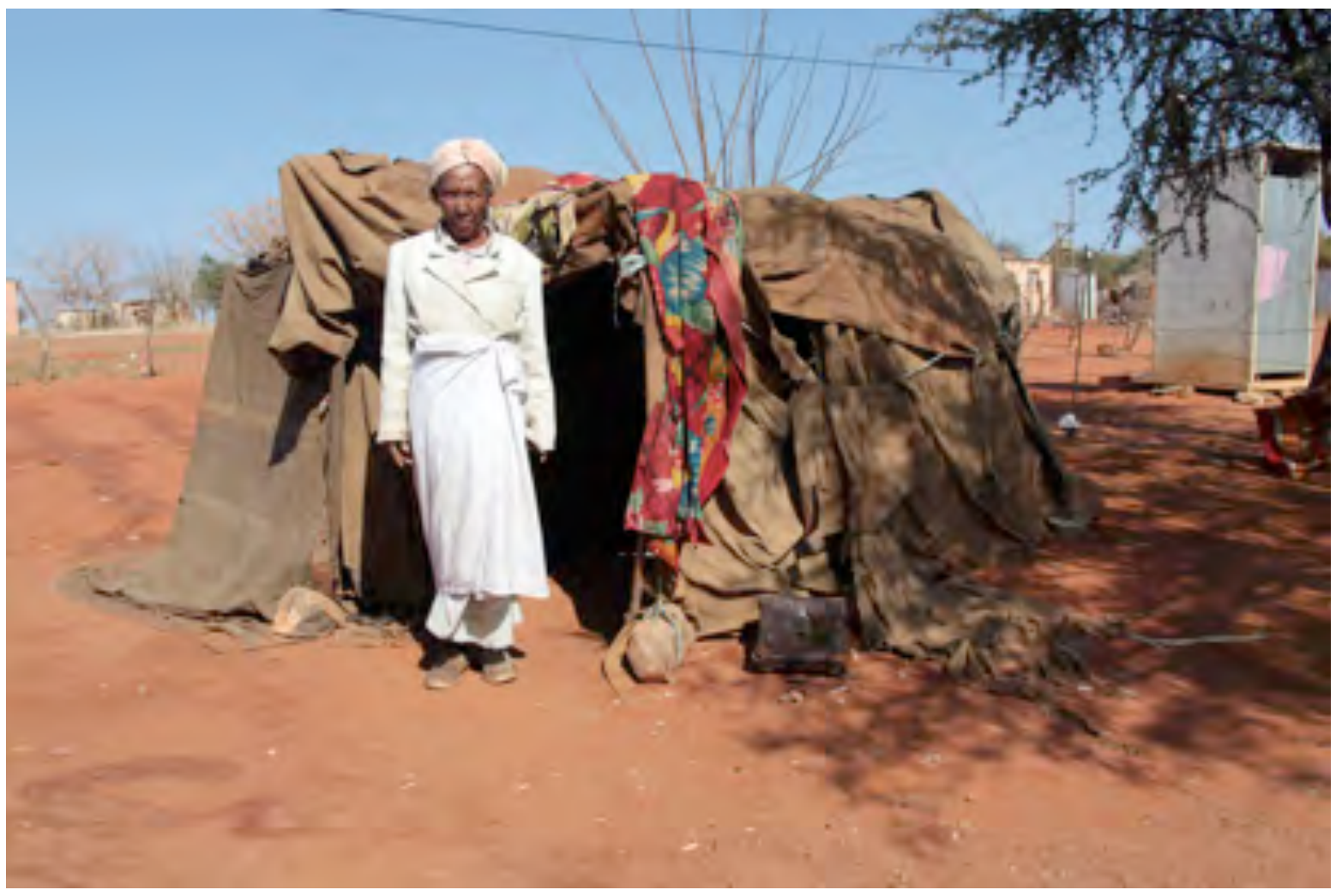

Figure 1 A makeshift kitchen outside a Platfontein dwelling. Some houses are home to a number of families. The structure is a typical San skerm (covering) made from old military tents to secure more domestic space (Photograph: JWN Tempelhoff)

In parts of the !Xun residential area of Platfontein some families make use of the traditional skerm (shelter) as an outside kitchen. Most are constructed from old army tents. These rudimentary kitchen areas sometimes include a storage facility for wood, a small fireplace and cooking utensils. A small basin for dishes is usually found near the skerm, or near the food preparation space inside the dwelling. Washing dishes is an important cultural tradition in the community. In former times housewives used sand to wash the dishes ${ }^{90}$ but these days they use commercial dishwashing detergents or resort to using laundry detergents. ${ }^{91}$

TOA20140816 Khwe (CPA), DSD: NK.

TOA20140815 Women, NGK, Platfontein: GM. 


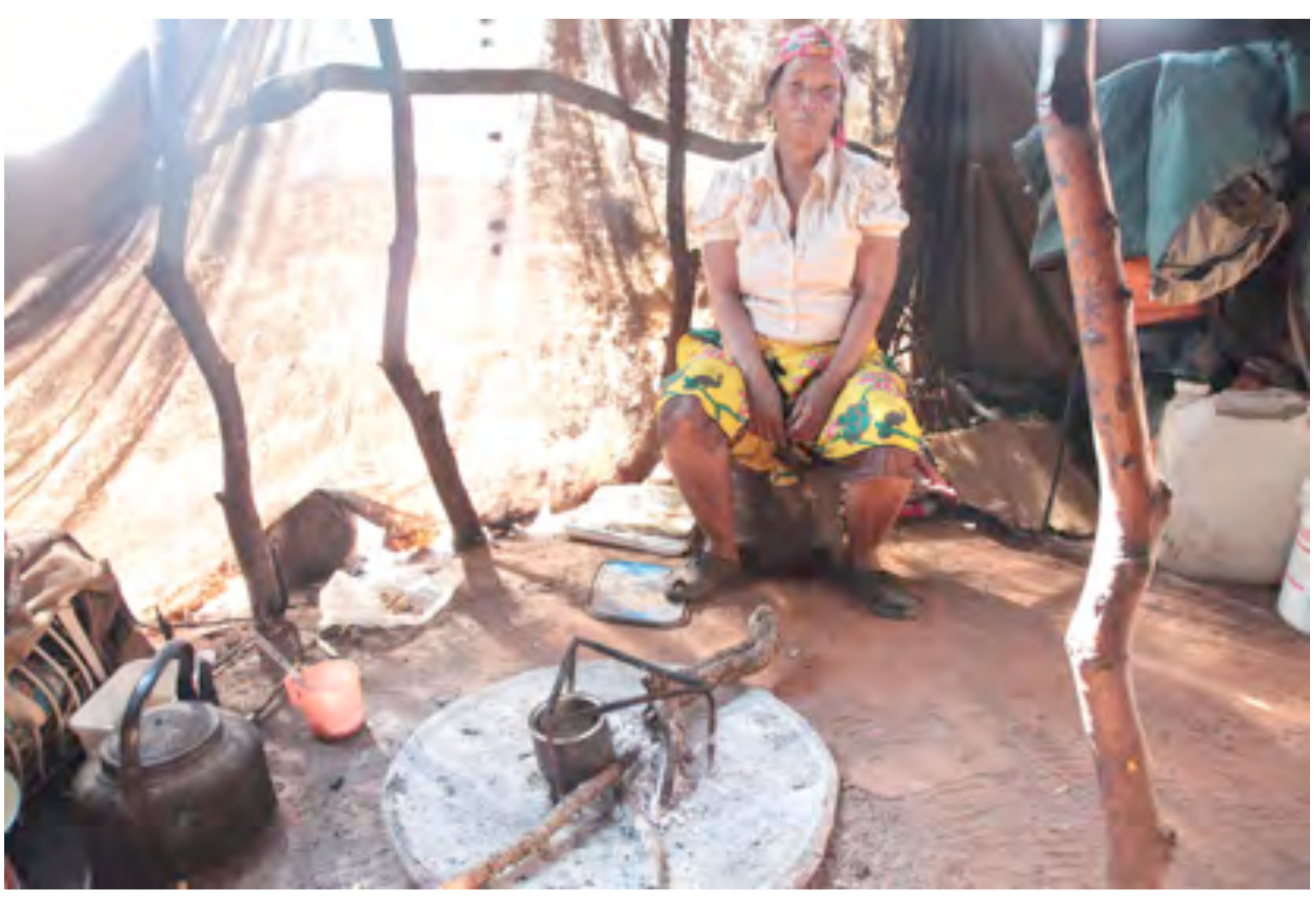

Figure 2 Some housewives use makeshift kitchens without proper ventilation and light (Photo: JWN Tempelhoff)

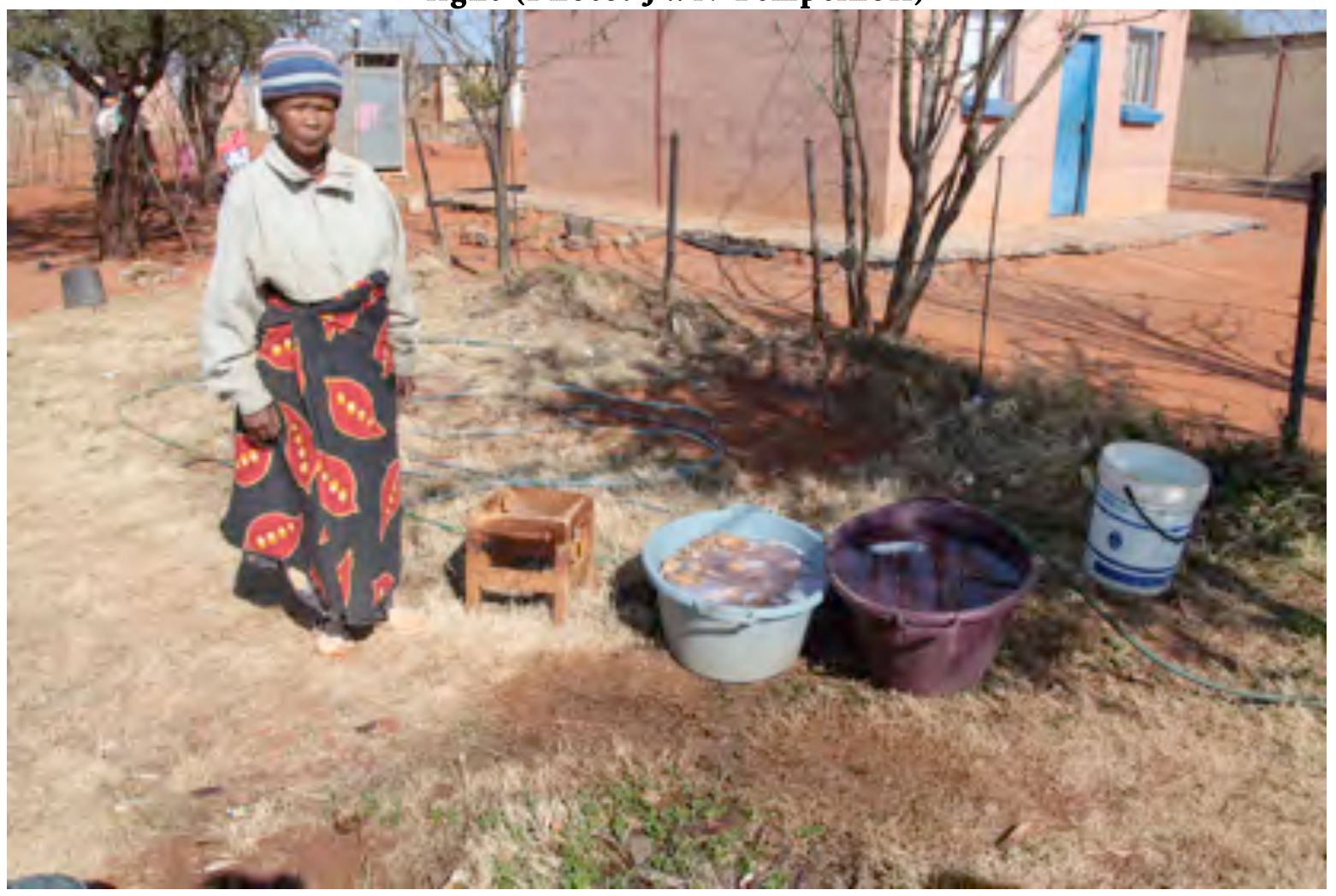

Figure 3 A senior member of the Platfontein community prepares to do the laundry. (Photograph: JWN Tempelhoff) 
It is difficult to perform all these tasks under crowded domestic conditions. A local leader explained that the children born between 1994 and 1998, many of them unemployed, are still living with their parents, placing severe strain on living space in the houses initially occupied in 2004..$^{92}$ The author was told that as many as four families (12-16 people) have to live in one dwelling. Residents complained that they have to go to great lengths before taking a bath. ${ }^{93}$ They are clearly aware of the facilities of other communities, and hinted that they also deserved proper water and sanitation services. ${ }^{94}$ In some households the bathtub was used for the family's laundry. ${ }^{95}$ Elderly people in particular experienced a dire need for hot water to at least have a daily wash. ${ }^{96}$ One explained that with a meagre supply of five litres he has to wash his whole body, shave and brush his teeth. ${ }^{97}$ This is a most unsatisfactory state of affairs for him in the large household of which he is the father.

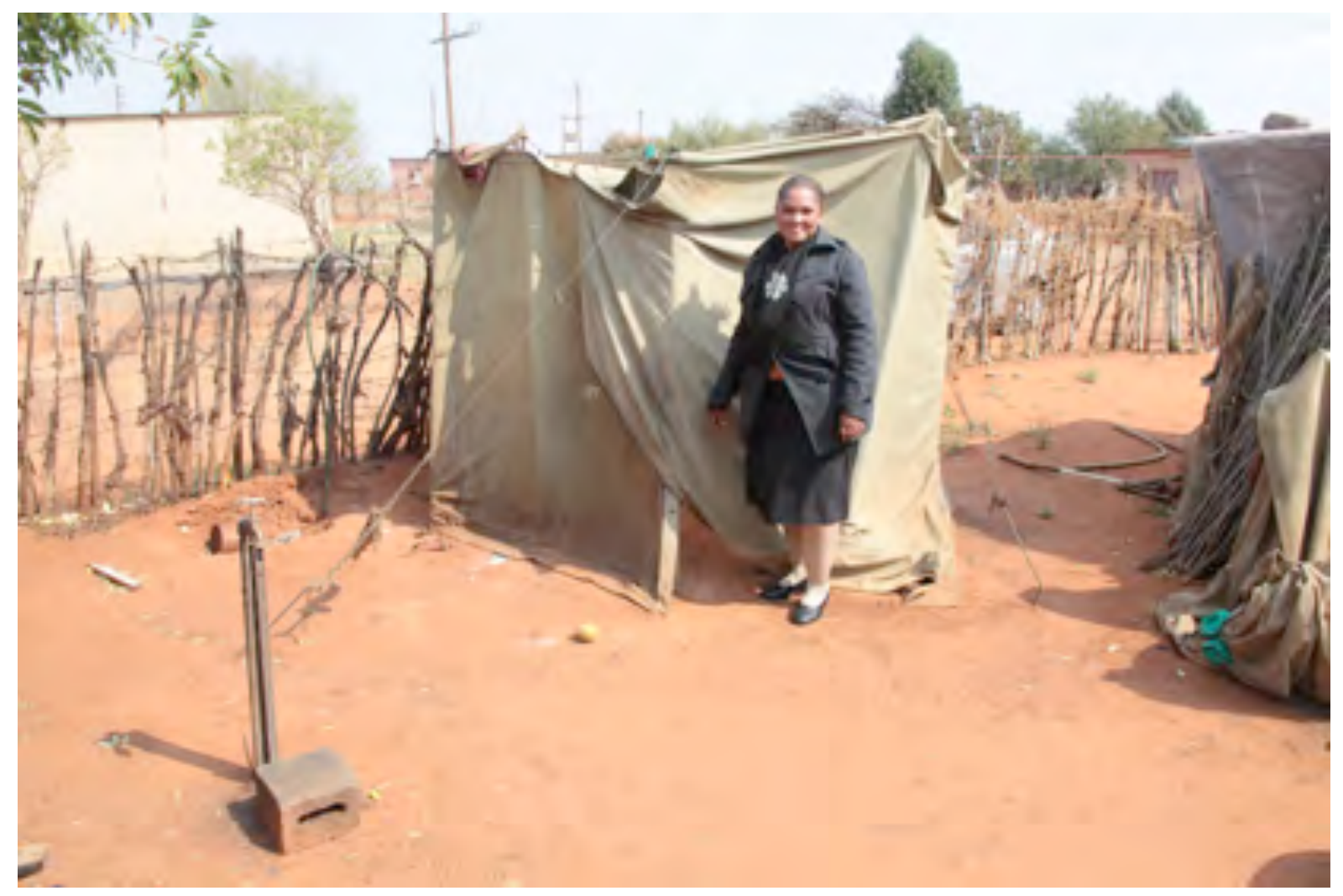

Figure 4 A makeshift cubicle made from the remnants of an old army tent serves as an enclosure for a respected traditional leader and his family to do their ablutions. During interviews local residents complained about the fact that they had insufficient space in which to perform their daily hygiene rituals (Photograph: JWN Tempelhoff)

\footnotetext{
92 TOA20140712 01 ZS, Roodevallei, Pretoria.

93 TOA20140815 !Xun and Khwe CPA, DSD, Platfontein: FMM.

94 TOA20140815 Women, NGK, Platfontein: GM.

95 TOA20140815 !Xun and Khwe CPA, DSD, Platfontein: FMM.

96 TOA20140815 Women, NGK, Platfontein: MN.

97 TOA20140712 01 ZS, Roodevallei, Pretoria.
} 
The existing washing arrangements have a marked effect on the workload of females in the household. Where there is no electricity the women are responsible for gathering firewood, which was not readily available in close proximity to the built-up township. Everything in Platfontein seems to demand significant human energy. There was a request for the municipality to install solar power to ensure that houses had the benefit of hot water. ${ }^{98}$ Apparently they had been promised prior to the May 2014 election that solar panels would be installed. However, by August 2014, nothing had been done. ${ }^{99}$

\section{Water leaks, outages and politics}

In mid-August 2014 there were many broken taps and leaking pipelines in Platfontein and local residents frequently complained to members of the CPA. ${ }^{100}$ At one time, a community leader recollected in an interview, that it was literally impossible to access the premises of the local school for three months because of a water leak at the front gate. ${ }^{101}$

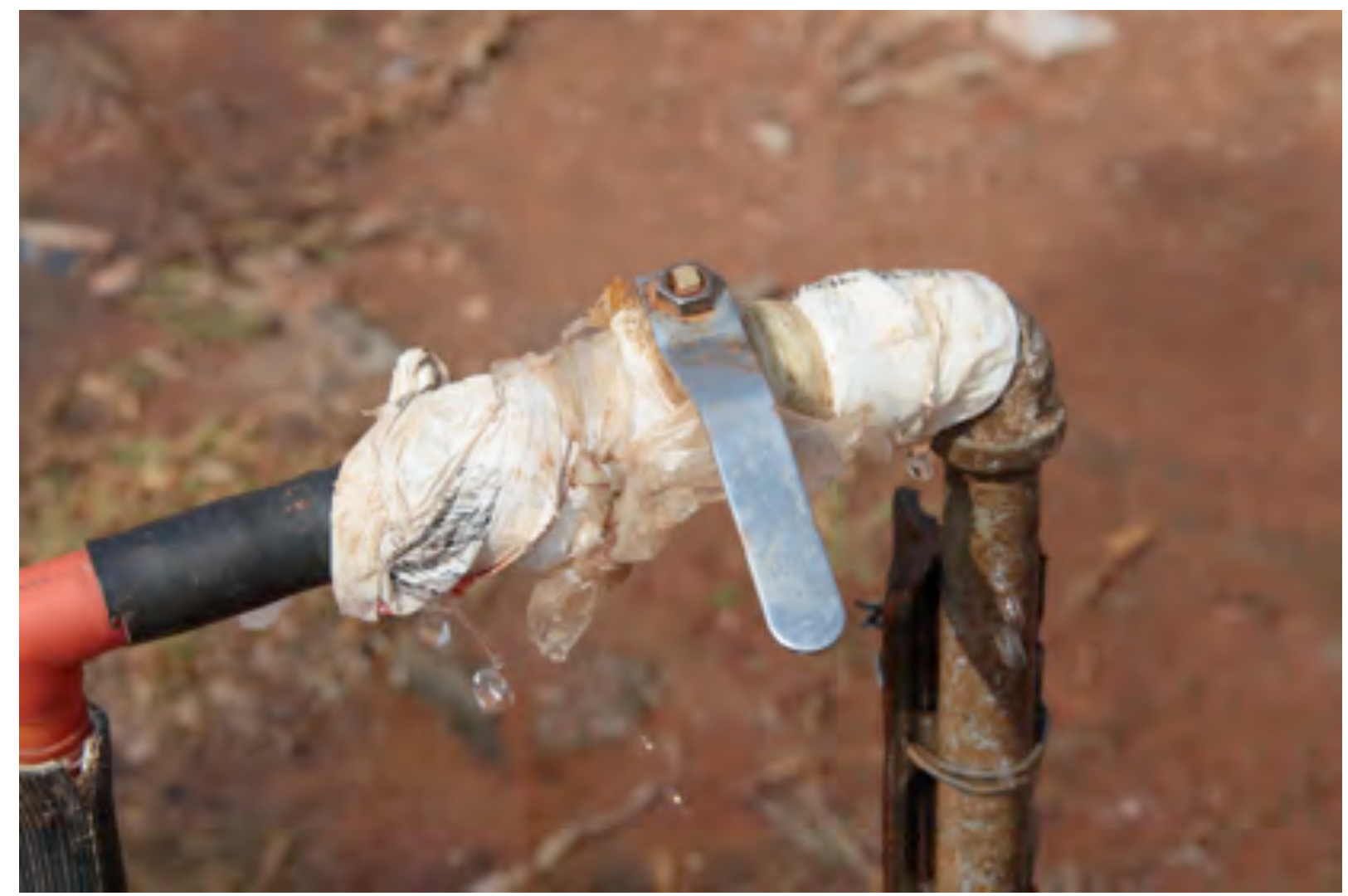

Figure 5 Some resident use plastic bags to stop tap leaks (Photograph: JWN Tempelhoff)

In informal discussions and in formal interviews, residents expressed the opinion that it was the responsibility of the municipality to come and repair the taps and the pipelines. ${ }^{102}$ One resident said that because the taps are located outside they must surely be the responsibility of

\footnotetext{
98. TOA20140815 Women, NGK, Platfontein: GM.

$99 \quad$ Ibid.

100 TOA20140815 !Xun and Khwe CPA, DSD, Platfontein: JD.

101 TOA20140815 !Xun and Khwe CPA, DSD, Platfontein: FMM.

102 TOA20140815 !Xun and Khwe CPA, DSD, Platfontein: JD.
} 
the municipality ${ }^{103}$ Other residents appear to be amenable to paying for repairs to the water supply on their properties, but do not always have sufficient money. ${ }^{104}$ In some cases community members resorted to self-help strategies. In the Khwe community's area in Platfontein, there are rudimentary but innovative strategies for conserving water and looking after taps by sealing them with strips of plastic from shopping bags. Residents in other parts of Platfontein use containers to store water that gushes from leaking taps.

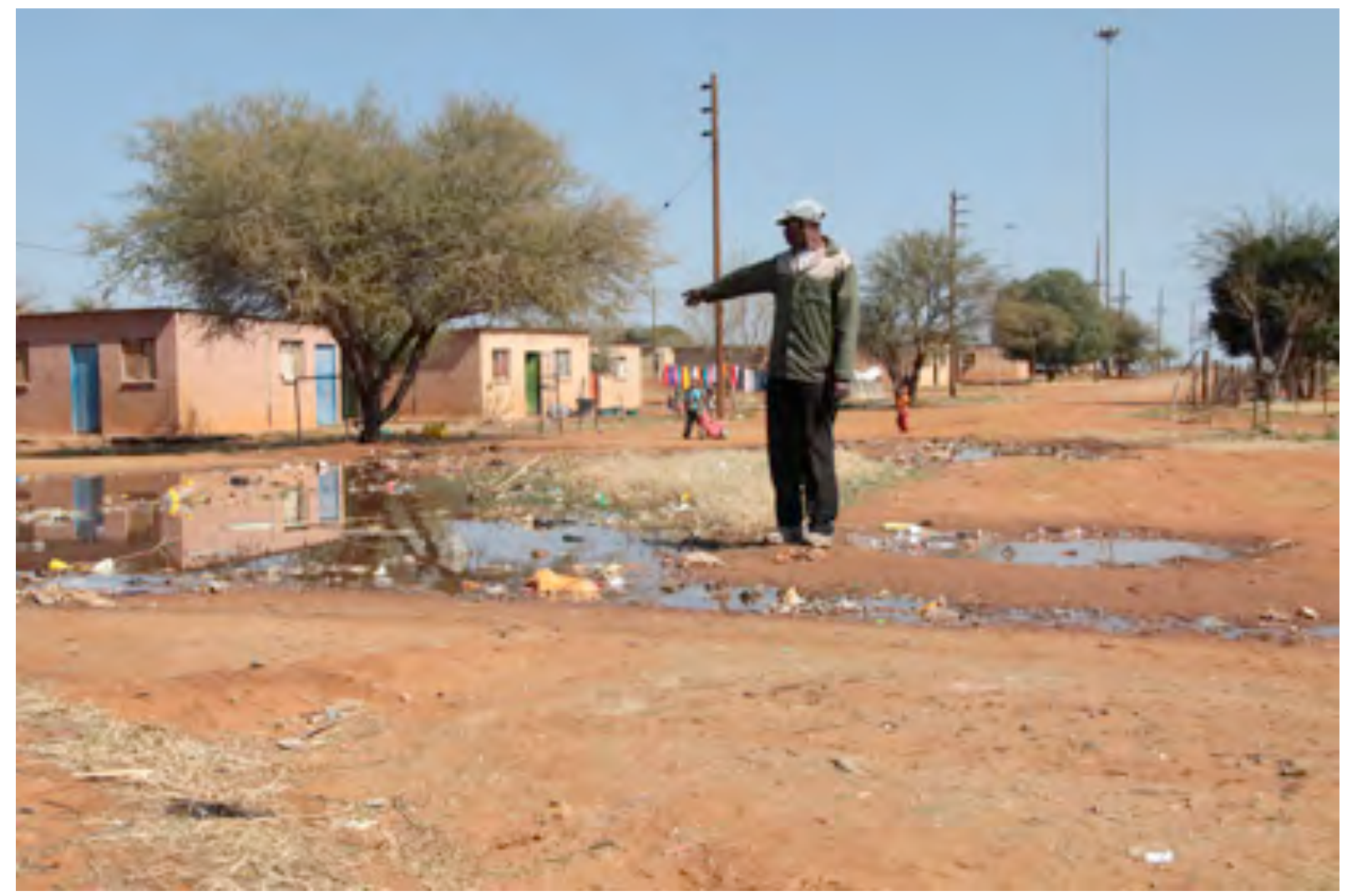

Figure 6 At the intersection of Kangulu Street in Platfontein's Xun area water is still dammed up, despite a recent water pipe repair operation. Motorists and pedestrians are unable to pass safely through the area (Photograph: JWN Tempelhoff)

Most water supply outages occur in the summer months. At times the community is without water for two to three days. They do receive prior notification of outages, so that they are able to store up sufficient supplies. ${ }^{105}$ One CPA leader explained that in many cases people had learnt when to expect outages:

When it is overcast there is water. However, when the sun shines we do not get water. In the summer we need water, but that is the time of year that they [the municipal officials] simply close down the water. ${ }^{106}$

104 TOA20140815 Women, NGK, Platfontein: DN.

105 TOA20140816 Khwe CPA, DSD, Platfontein: MJ.

106 TOA20140815 !Xun and Khwe CPA, DSD, Platfontein, Platfontein: RM.
} 
The community felt there should be a standing arrangement with the municipality about water cut-offs. If there were outages, people had to be informed of the state of affairs. ${ }^{107}$

Water leaks and outages in Platfontein determine how local residents interact politically with the Sol Plaatje Local Municipality in Kimberley. One leader explained that the strongest argument against taking personal responsibility for water leaks in the community is that the municipality had not completed the job properly. By August 2014, many of the houses did not have adequate water supplies and electricity connections. ${ }^{108}$

Recently the community had pointed a finger at the municipality when a local resident allegedly drowned in a pool of shallow water caused by a leaking water pipe in the street. Residents told the media how a weeping Mrs Marianna Tjina (62) dragged the lifeless body of her husband, Phemelo, from the water and covered him with a blanket. There was considerable anger in the community, because several weeks earlier they had informed the municipality of the leaking pipe in Ove Street. The pipeline was only repaired after $\mathrm{Mr}$ Tjina's death. ${ }^{109}$

\section{Paying for services and relations with the municipality}

Many residents of Platfontein are opposed to paying for municipal services. Some argue that it is unacceptable that people have to pay for water when in former times it was free. ${ }^{110}$ Community leaders explained that Platfontein residents do not in fact consume much water. Besides, they do not have waterborne sanitation, which tends to consume a lot of water. They essentially use water for preparing food, washing dishes and personal hygiene. ${ }^{111}$ Importantly, residents argued, they are not getting a fair deal from the local authority. They singled out a number of issues.

The construction of their houses, a project started in 2003, had not been completed by August 2014. ${ }^{112}$ One of the three residential housing zones in the !Xun part of Platfontein had never been provided with electricity or proper water services. ${ }^{113}$ Many residents had not yet received the title deeds to their homes. Residents complained of the shoddy manner in which the houses were built. There are many examples of leaking roofs and deteriorating wall structures ${ }^{114}$ and the foundations of some of the houses have deteriorated. There is general discontent with water and sanitation service delivery. The services are irregular and are often haphazard. A notable feature of service delivery is its inconsistency. Neighbouring townships had far better housing, toilet facilities and water supplies than the residents of Platfontein.

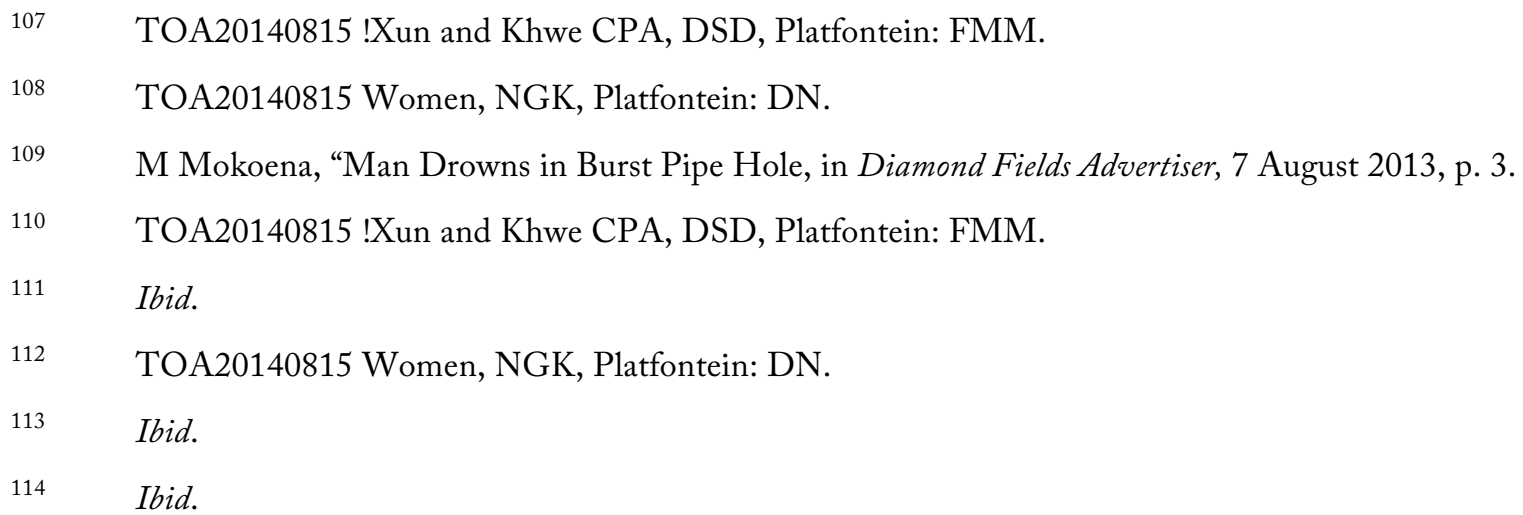


The local municipality and its representatives seem to have an unsavoury reputation in the community. CPA leaders said there were concerns about inaccurate water bills not reflecting the real consumption of local residents. ${ }^{115}$ Written submissions to the municipality were ineffective; it appeared that officials simply put the correspondence aside. ${ }^{116}$ The people were also upset that if and when bills went unpaid, the municipality would not cut off the water, but only the electricity. ${ }^{117}$ They considered this an injustice because residents were then "kept hostage" with regard to water and forced to engage with the municipality over their problems. ${ }^{118}$

Some said they were hesitant to complain to the municipality about the state of affairs in the township. An elderly lady, who has the title deed to her property, said that she has not received fair and reasonable treatment from the municipality. When she complained to the authorities about the faulty electricity supply the municipality's technicians merely dismantled the connection without restoring the power supply. Officials failed to respond to her subsequent telephone calls. ${ }^{119}$ People also said that if residents called the municipality, their accounts would first be checked to see if their rates payments were in arrears. If they defaulted on payments, the supply of both water and electricity to their homes would be in jeopardy. The uncertainty about how the local authority's officials would respond makes Platfontein residents fearful of engaging with the municipality. The prevailing state of affairs appears to have far-reaching implications for Platfontein's residents: according to one community leader, local residents are not registered on the municipality's indigent register. According to a Khwe CPA member, provision has been made at Roodepan, a former township for coloured people, for unemployed local residents to be listed as indigents. The amount of their contributions for municipal services was then negotiated as part of government's support for the needy in local communities. ${ }^{120}$

People felt hurt when nothing worked; did the municipality not care about them? ${ }^{121}$ The women recollected how in former times the SADF would come in and do repairs to the infrastructure. If there was no water supply in the camp at Schmidtsdrift, the SADF would truck water in. ${ }^{122}$ The general feeling was that the municipality should come to their assistance. $^{123}$ The leadership expressed the opinion that their community had been marginalised in matters of municipal governance. None of Platfontein's residents were employed as officials at the municipality, and they believed that if local residents were employed as officials the community's interests would be better served. ${ }^{124}$ Housewives said

\footnotetext{
115 TOA20140815 !Xun and Khwe CPA, DSD, Platfontein: JK.

116 TOA20140815 Women, NGK, Platfontein: PV.

117 TOA20140815 !Xun and Khwe CPA, DSD, Platfontein: N.

118 TOA20140815!Xun and Khwe CPA, DSD, Platfontein: FMM.

119 TOA20140815 Women, NGK, Platfontein: AC.

120 TOA20140816 Khwe (CPA), DSD: PC.

121 TOA20140815 Women, NGK, Platfontein: JD.

122 TOA20140815 Women, NGK, Platfontein: GM.

123 TOA20140815!Xun and Khwe CPA, DSD, Platfontein: N.

124 TOA20140816 Khwe (CPA), DSD, Platfontein: MJ.
} 
that if community members were appointed they would transmit the proper message from the community to the municipal officials and political leaders on conditions at Platfontein. ${ }^{125}$

\section{Sanitation}

Many people in Platfontein are reluctant to talk about the state of sanitation, because it is a constant refrain. The inferior sanitation infrastructure is allegedly a major cause of disease in the township. ${ }^{126}$ At the time of conducting fieldwork in August 2014 the author noticed that local people have to walk into the veld for the purposes of urinating and defecating. This is symptomatic of a special set of conditions. According to one resident, if the toilets are full (meaning the plastic toilet bags have not been removed from the pits by the local contractor) then people resorted to going into the veld. ${ }^{127}$ One community member asked: "Why is it that other communities get waterborne toilets, while the people of Platfontein are overlooked?" 128

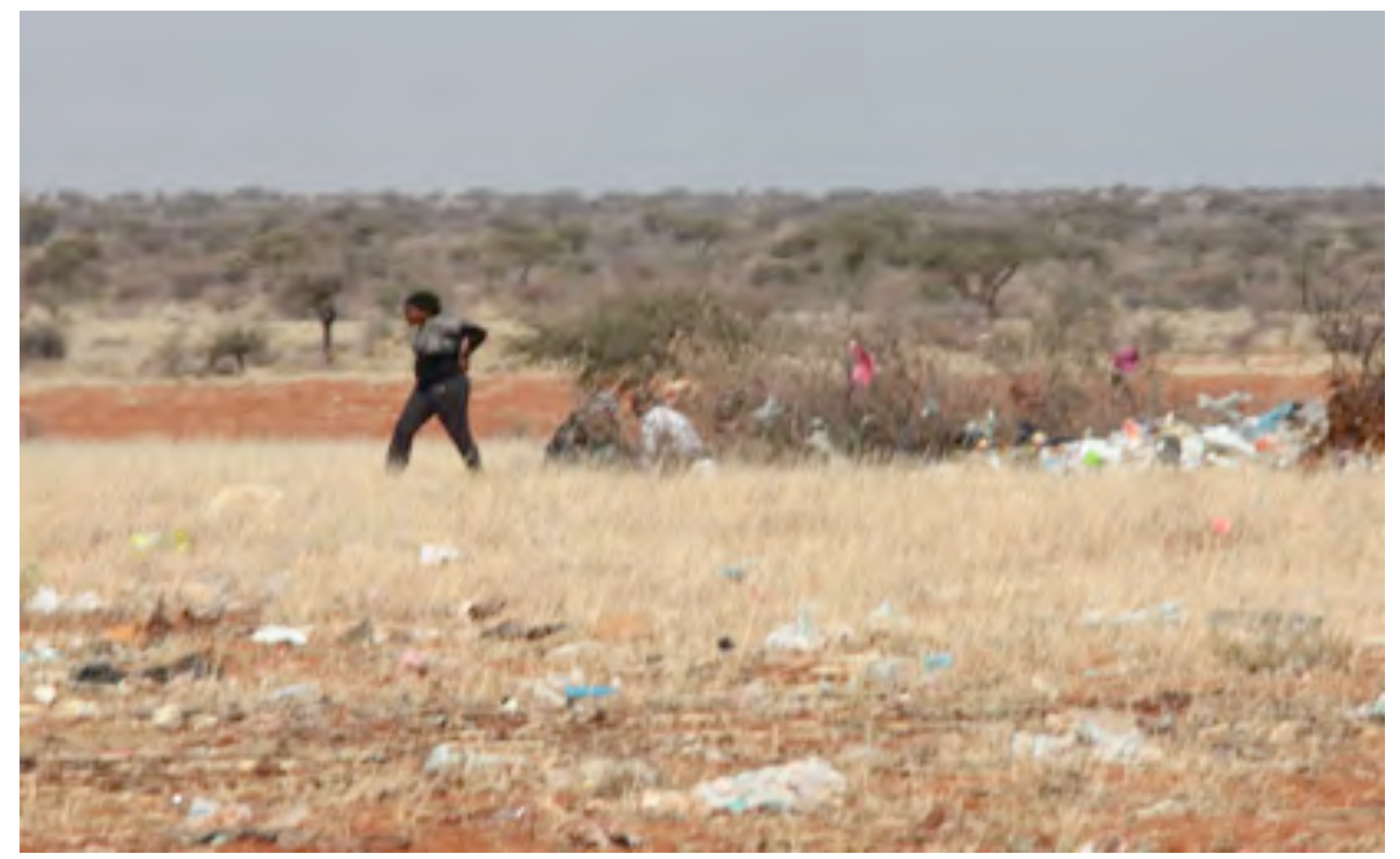

Figure 7 Many residents resort to making use of open spaces in the township or on the periphery of the township to relieve themselves. Residents find the stench from local toilets unbearable (Photograph: JWN Tempelhoff)

Local discontent with the state of sanitation has a long history. The absence of proper waterborne sanitation was at the heart of a dispute between the San of Platfontein and the government at the time of their relocation in 2004 from Schmidtsdrift. Within four months of their arrival community members were asked to participate in the national election.

\footnotetext{
125 TOA20140815 Women, NGK, Platfontein: PV.

126 TOA20140815 !Xun and Khwe CPA, DSD, Platfontein: RM.

127 TOA20140815 !Xun and Khwe CPA, DSD, Platfontein: FMM.

128 TOA20140815 !Xun and Khwe CPA, DSD, Platfontein: RM.
}

Td, 10(4), December 2014, pp. 52-83. 
However, 15 members of the community declined to do so, apparently at the behest of the Reverend F Mario Mahongo, leader of the !Xun, who told the people that he did not want them to vote. Consequently, only 148 people of Platfontein voted. ${ }^{129}$ The major complaint was having to make do with dry toilets. ${ }^{130}$

Local government MEC Pakes Bikgetsi, who personally made enquiries to find out why so few residents had voted, was told that the people were unhappy about the way they had been treated by the SADF in Angola and Namibia and that the promises that had been made to them while they were in the employment of the SADF had not been fulfilled. ${ }^{131}$ There was little or no change by 2004. Bikgetsi told the media he had informed the community that the government had kept its side of the deal that had been concluded with them. He claimed that there were still 350 families living at Schmidtsdrift and once these people had joined the others at Platfontein waterborne sanitation would be provided. ${ }^{132}$ At the time Mahongo was still living at Schmidtsdrift. He let it be known that he would be the last to move to Platfontein, once all the people had received their houses. ${ }^{133}$ In August 2014, it was apparent that the government had not kept this promise. Residents frequently mentioned that hardly any of government's promises of proper sanitation had materialised. ${ }^{134}$ An irate resident said: "They promised us toilets. The government has not yet come to do what they had promised to do." 135

Community members noted that they saw how flush toilets worked at the "One Stop Centre" (a shopping area in Kimberley) and felt they had reason to be dissatisfied about the sanitary conditions under which they had to live. ${ }^{136}$ One said that despite being unemployed he preferred making use of pay-toilets whenever he visited Kimberley. ${ }^{137}$ An angry resident said: "We did not leave Namibia to remove our own stool from the toilet and put back an empty bucket." ${ }^{38}$ Another complained:

It is when we have to clean the toilets that we become sick. When the bags are removed they are placed in front of the houses and then people become sick. ${ }^{139}$

Sapa, Northern Cape MEC to Visit the San King, in IOL, 12 April 2004, Accessed 7 September 2014, http://goo.gl/haOXv7

Sapa, San People Start Voting, in IOL, 14 April 2004,Accessed 7 September 2014, http://goo.gl/zQCqch

131 Ibid.

132 Ibid.

133 Sapa, Northern Cape MEC to Visit the San King

134 TOA20140815 Women, NGK, Platfontein: MN.

135 TOA20140815 Women, NGK, Platfontein: AC.

136 TOA20140815 Women, NGK, Platfontein: AC.

137 TOA20140712 01 ZS, Roodevallei, Pretoria.

138 TOA20140815 Women, NGK, Platfontein: AC.

139

Ibid.
} 


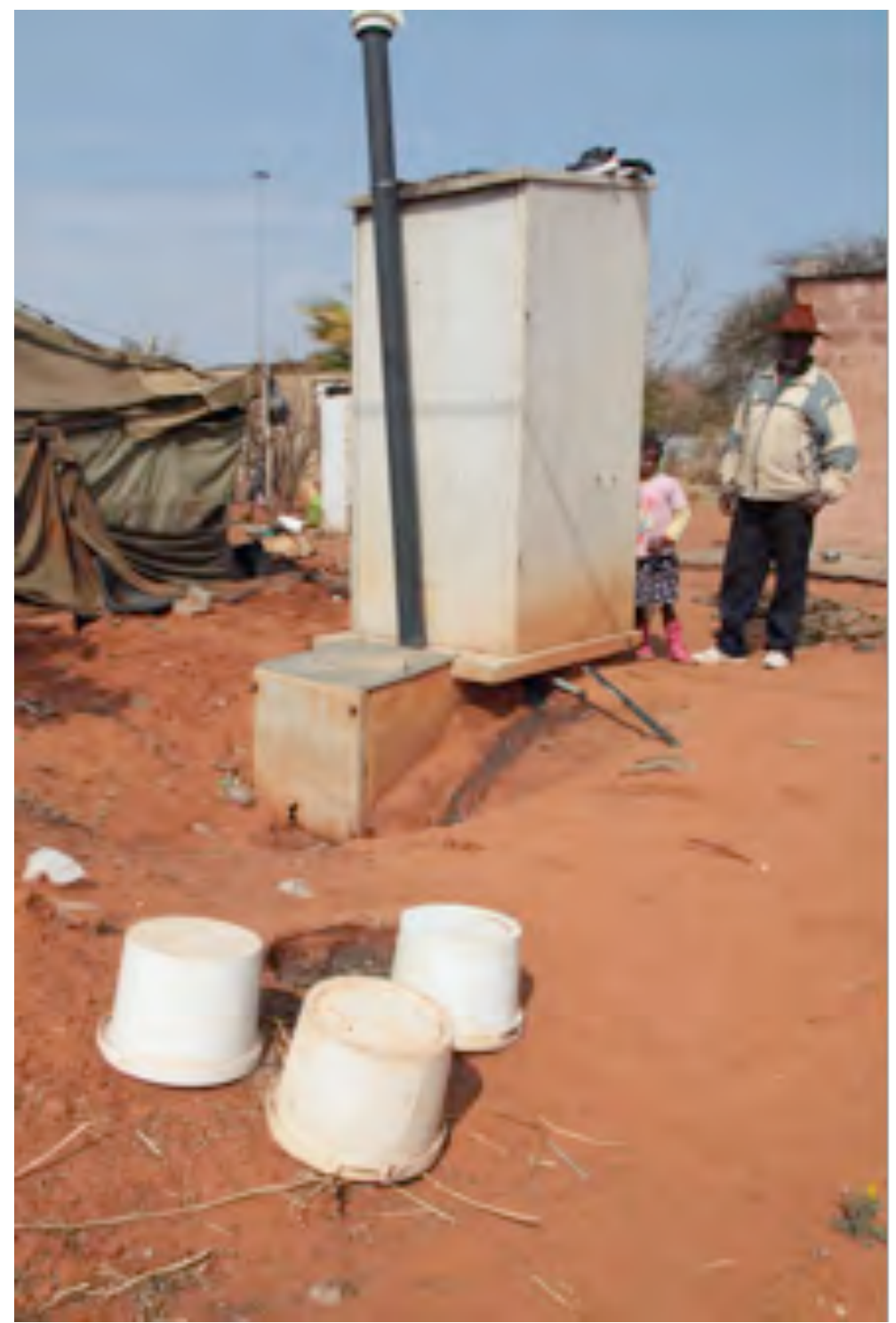

Figure 8 Out of sheer desperation this toilet has a pipe extension for raw sewage to run down in a hole adjacent to the toilet bag container. In the foreground are a number of plastic containers for faeces that are emptied into the hole at the back (Photograph: JWN Tempelhoff)

At houses where there are toilets, the pipes into the plastic bags are often broken. In some cases the steel parts of the toilet no longer work properly. ${ }^{140}$ One resident said that it was offensive for people to smell the toilets of their neighbours. ${ }^{141}$ Others explained: "Even when you sit outside in the sun you get the smell of the neighbour's toilet," ${ }^{142}$ and: "Whenever you eat you get the whiff. This spoils the taste of the food people eat." ${ }^{143}$

\footnotetext{
$140 \quad$ Ibid.

141 TOA20140815 Women, NGK, Platfontein: SC.

142 TOA20140815 !Xun and Khwe CPA, DSD, Platfontein: RM.

143 TOA20140815 Women, NGK, Platfontein: SC.
} 
The smell from the toilets should not be noticeable because they are not situated very close to the houses. The problem is that toilets are filled to capacity.

The sanitation problem is not confined to the township's housing. At the local school there are similar problems. One Platfontein resident observed: "If you see the children at school not making use of the school's toilets it is because they are dirty." 144

The irregularity of the sanitation services in Platfontein is a major concern. ${ }^{145}$ People experience considerable problems when they personally have to fit the bags. ${ }^{146}$ Dirty and dysfunctional toilets are reportedly the cause of people becoming sick. ${ }^{147}$ Over the years there have been many meetings about experimental toilets but as yet there is no improvement. By August 2014, people were demanding that toilets be provided in their homes. ${ }^{148}$ One respondent said that toilet technologies that did not work in the Western Cape Province were being exported to the Northern Cape Province. ${ }^{149}$ People were tired of all the futile efforts to address the complex issue of sanitation. It was felt the unhygienic conditions under which members of the community lived also jeopardised their safety: people did not know what to expect outside their homes if they went outdoors at night. ${ }^{150}$ In a group interview community members nodded in the affirmative when one of the speakers mentioned the time when a female resident of Platfontein had been raped when she went outdoors to use the toilet at night. ${ }^{151}$ A local leader explained that he felt embarrassed when people came to visit his home and he had inferior sanitary arrangements in the household. It felt to him as if people would think that all the residents of Platfontein were living dirty lives. ${ }^{152}$

\section{Discussion}

It is apparent from the fieldwork visit and discussions with numerous people in Platfontein that the community live under conditions that in some respects resemble typical life in South Africa. At the same time - especially as far as water and sanitation services are concerned some conditions resembled those of informal settlements where people had to secure their own water supplies and also make do with unhygienic sanitation conditions.

The researcher visited the municipal offices and spoke to a senior official on 12 August 2014 to request a collaborative initiative to get to a better understanding of the water and sanitation problems of the Platfontein community. The responsible engineer was a new appointment and still unfamiliar with all the local conditions. There was a verbal agreement that he would secure documentary information on the water and sanitation infrastructure in Platfontein, but this has to date not materialised, despite a number of e-mails and telephone

\footnotetext{
$144 \quad$ Ibid.

145 TOA20140815 !Xun and Khwe CPA, DSD, Platfontein: RM.

146 TOA20140815!Xun and Khwe CPA, DSD, Platfontein: FMM.

147 TOA20140815 Women, NGK, Platfontein: SC.

148 TOA20140815 !Xun and Khwe CPA, DSD, Platfontein: RM.

149 TOA20140815: !Xun and Khwe CPA, DSD, Platfontein: FMM.

150 TOA20140815!Xun and Khwe CPA, DSD, Platfontein: N.

$151 \quad$ Ibid.

152 TOA20140815 !Xun and Khwe CPA, DSD, Platfontein: FMM.
} 
calls. An obliging official of the Northern Cape provincial division of the DWS later provided information on Platfontein. From the water and sanitation maps (see above), it is evident there is no proper water and sanitation. This has been the state of affairs since 2004 when the contractors responsible for building the houses left the site.

There are many leaking pipelines in Platfontein. In some parts pedestrians and even motorists refrain from passing through the settlement because of the dangers posed by the muddy areas. In other areas, people have laid out gardens that they irrigate from leaking pipelines and taps. It is also evident that the water supply does not have sufficient pressure, which means that some of the houses situated at higher elevations in town will not always receive a constant water supply.

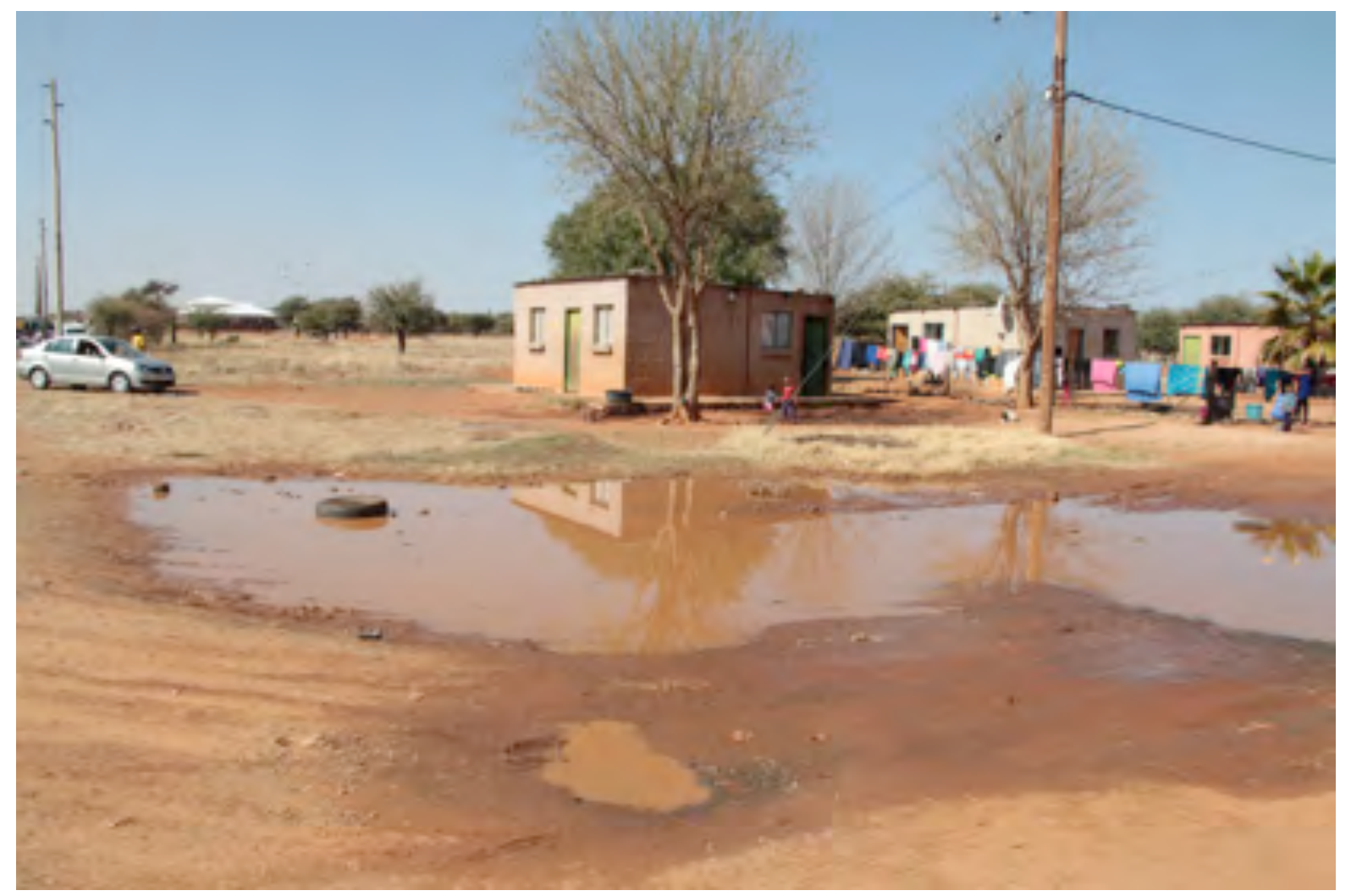

Figure 9 A pipe leak at a $T$-junction into Kamatoka Street, the main road of Platfontein. In the rainy season the nearby houses are frequently flooded causing significant damage to residents' domestic belongings (Photograph: JWN Tempelhoff)

In respect of sanitation, it is evident that people live under difficult conditions. If it rains there is flooding because of a lack of proper stormwater drainage. Moreover in wet weather the filthy toilet bags that are replaced irregularly by sanitation workers contaminate all the water around the dwellings. The San community is a transitional one faced with severe challenges to their resilience in living up to the expectation of a better life in a rapidly urbanising South Africa. Not only does having to make use of the veld for toilet purposes take away their dignity; it is in direct conflict with the basic human right to live in an environment that is not dangerous to health. 
In 2007 an 84-year-old resident of Platfontein told a journalist that he felt trapped in the community where he lives in his sparsely furnished home. ${ }^{153} \mathrm{He}$ explained:

My father taught me how to hunt with a bow and arrow. We slept in the veld - it was so free. But that has all been taken away, we can never go back..$^{154}$

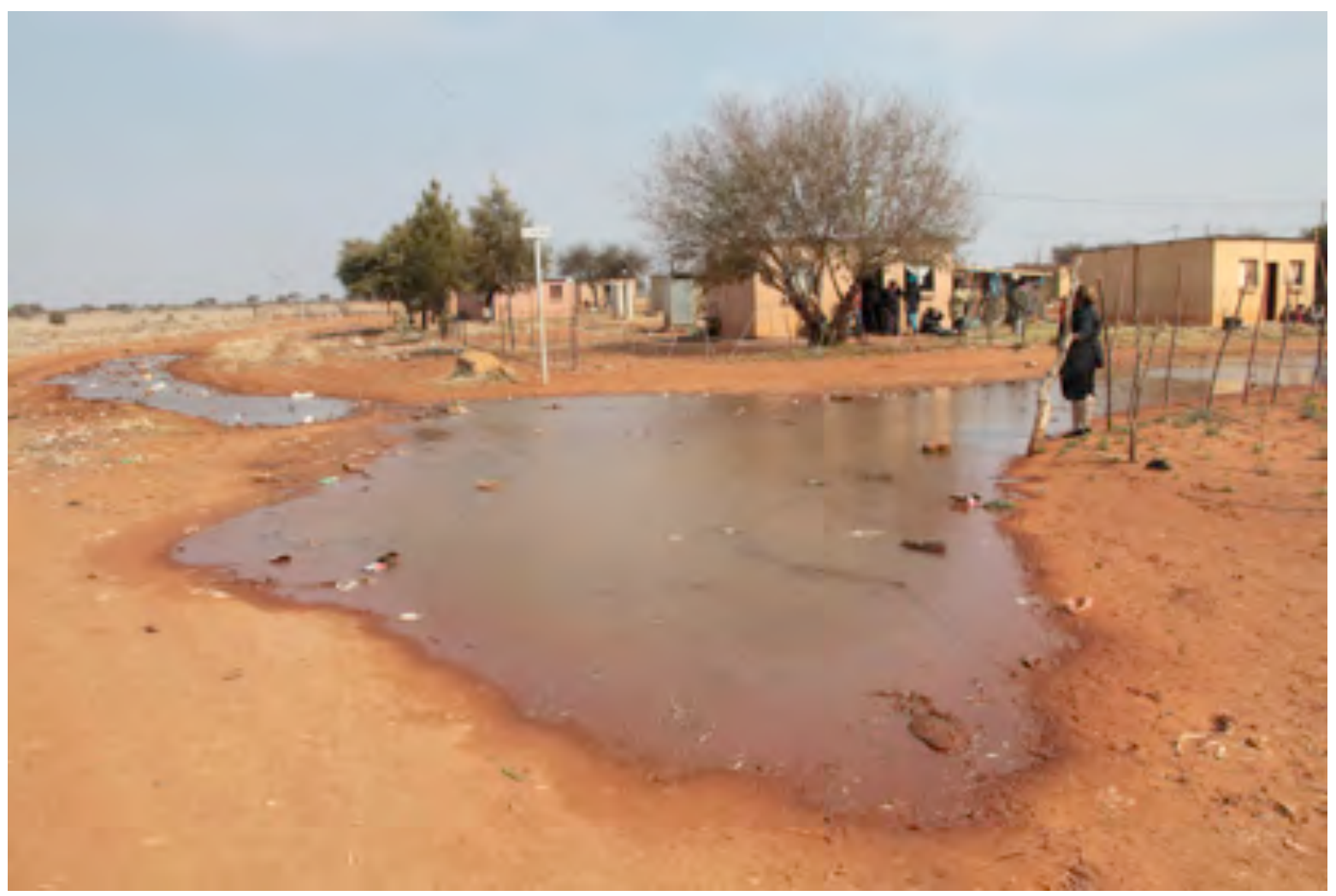

Figure 10 Motorists are unable to use the Chere Street $T$-junction road for fear of damaging their vehicles in the leaking water on site. (Photograph: JWN Tempelhoff)

Caught up in the social process of urbanisation at the time, both the !Xun and Khwe communities in the township felt they had been reduced to relying on government pensions and food handouts. ${ }^{155}$ In 2004, after arriving at Platfontein, community leader Mario Mahongo expressed the community's gratitude for the opportunity to acquire their own homes. The people were unemployed, he said, but they were grateful "to have something to start with". ${ }^{156}$ This "start" has not progressed as far as access to basic services is concerned. The conditions under which the San community live at Platfontein leaves much to be desired. The people are poor; most survive on the pension money the elders in the

\footnotetext{
153 Weidlich, San Face Lifestyle Threat.

154 Ibid.

155 Ibid.

156 M Smith, Long Wait for !Xun and !Khwe Homecoming Ends, in IOL, 20 January 2004, Accessed 7 September 2014, http://goo.g1/no9Gcs
} 
community receive. Few were employed, ${ }^{157}$ including some of the former soldiers. There are rare exceptions, such as, 32-year-old Dall Paulus, who worked out a plan to sell sour marog, ${ }^{158}$ in the nearby townships of Kimberley. ${ }^{159}$

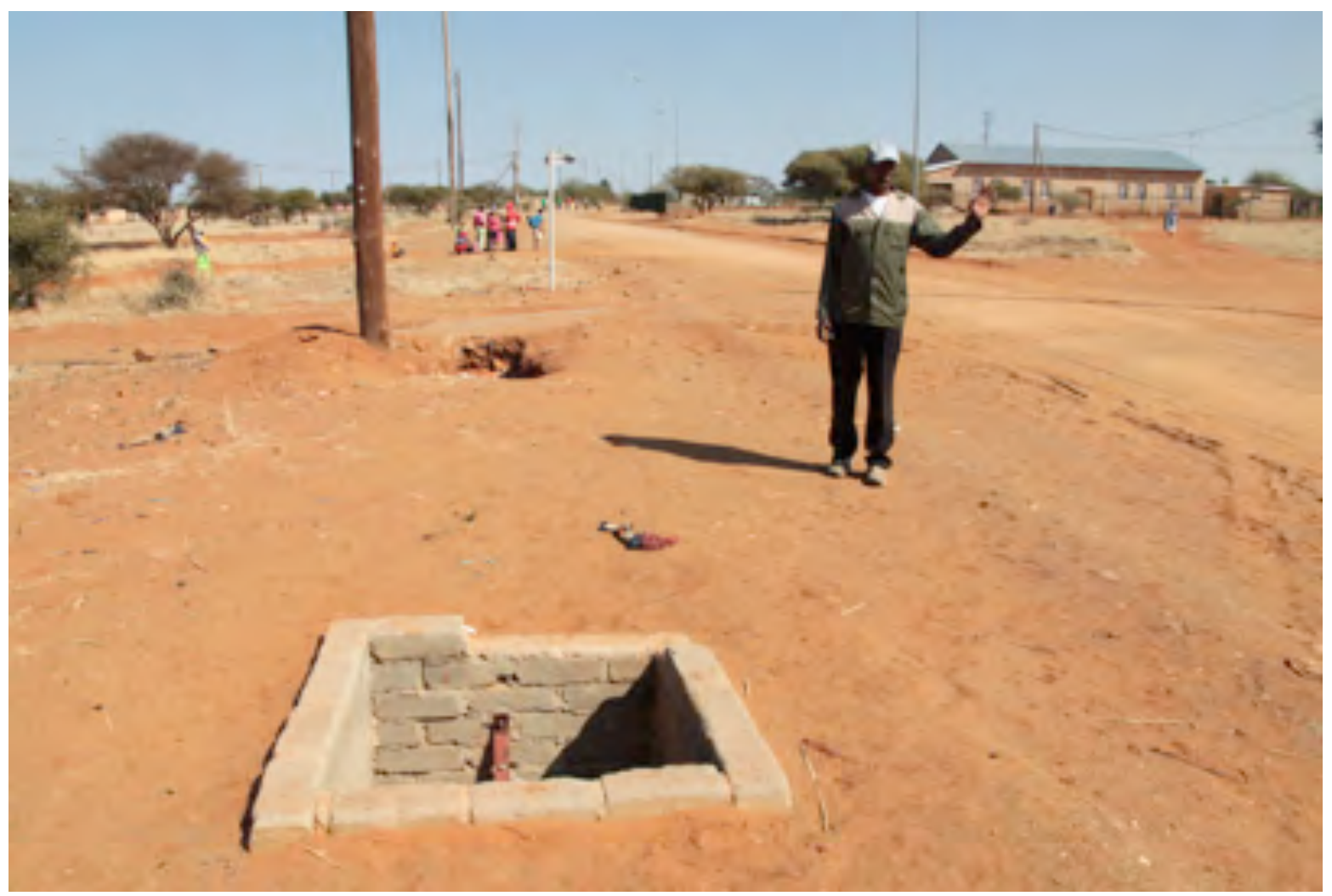

Figure 11 When a local community leader pointed out this pit, presumably for sewage bags and/or refuse, small children jumped out of the pit. They had been playing in the pit and another (in the background) in which there were traces of faeces (Photograph: JWN Tempelhoff)

In 2007, people were complaining that they did not have employment. There were still only a handful of people with jobs and transport to town was hard to come by. ${ }^{160}$ In 2013, it was estimated that about 90 per cent of the economically active people in the Platfontein community (estimated to be at least 800 people) were unemployed, ${ }^{161}$ and by 2014 the situation had not changed much. No local residents work as officials at the municipality. They are thus far away from the centre of municipal authority and still on the fringe of an emergent urban social ecology. In discussions on the appalling conditions at Platfontein, the idea was mooted that the municipality should appoint local residents. Perhaps the time has

Smith, Long Wait for !Xun and !Khwe Homecoming Ends.

Amaranthus hybridus, also known as marogo or tepe (Sotho), umfino (Zulu), misbredie (Afrikaans) and pigweed (English) is a nutritious type of spinach, endemic in many parts of southern Africa and eaten as a leaf vegetable by indigenous peoples. Other varieties found on the subcontinent, include $A$. Thunbergii, A. Spinosus, A. Deflexus. See B-E van Wyk and N Gericke, People's Plants: A Guide to the Useful Plants of Southern Africa, Briza Publications, Pretoria, 2007, pp. 64-65.

Smith, Long Wait for !Xun and !Khwe Homecoming Ends .

Weidlich, San Face Lifestyle Threat.

N Wildenboer, Platfontein Community Sorry about Abraham the Camel, in IOL, 29 August 2013, Accessed 7 September 2014, http://goo.g1/p7OVbJ 
come for the municipality to open up a local office in Platfontein where residents are able to engage with municipal officials to pay their rates and also secure important social services from governance authorities. Furthermore, the request by a local leader that a swimming pool be built for the children of the community came across in a group discussion as a good idea. Currently, in the summer local children go down to the wetlands and play in the water, not knowing that a substantial amount comes from the raw sewage of the Gogga Pump station. ${ }^{162}$ The suggestion was also made that the local graveyard should be kept in a better condition and a proper urban park should be created. Both these ideas found support in the group.

Prior to the community's move in 2004 , they were described as a community in transition. ${ }^{163}$ In 2004, there was a spark of hope for a better future. Three years later there was talk about how the new generation of San, after attending the modern local school, would be able to seek out employment once they had completed their studies. ${ }^{164}$ However, the process of integration with the urban lifestyle has been difficult for many of the community.

By 2004, Platfontein residents felt that they were looked down upon by members of the community in Kimberley. In meetings and deliberations they would be described as the Tsqwitswi, meaning that they speak in clicking sounds. Members of the San community are of the opinion that the name now has derogatory connotations. ${ }^{165}$ This despite the fact that the San had tried to integrate with other residents of the Northern Cape provincial capital. Some Platfontein residents have already moved to neighbouring Galeshiwe.

A local community leader summed up the situation:

We were provided with houses, only to find out that when we returned from work the windows of our houses were broken and our belongings stolen. Because we are a peaceloving community and do not want to live in conflict with our neighbours we decided to return to Platfontein. We are not used to crime and find conditions in our community more amenable. ${ }^{166}$

One Khwe member of the CPA, a traditional leader who is employed in the post-1994 SANDF has moved to the Roodepan township, where he and his family have been accepted by the local community of primarily Namaqua and Griqua residents. The arrangement is better for him and his family: he is closer to his place of employment and the housing conditions in Roodepan are better than those at Platfontein. He and his family nevertheless maintain close ties with their friends and relatives at Platfontein. ${ }^{167}$

\section{Conclusion}

The anthropologist Tim Ingold, in one of his studies, draws a comparison between culture and cloud formation and notes that:

TOA20140815 !Xun and Khwe CPA, DSD, Platfontein: FMM. 
Cloud formation ... results from the aggregate interaction of a 'vast number of approximately equal particles', often closely coupled, and undergoing more or less random motion. Watching the cloud grow, we observe that nothing is quite the same from one moment to the next ... ${ }^{168}$

There appears, he explains, to be a continued change in the direction of the absolutely new. ${ }^{169}$ If one were to contemplate cultural change from a sociobiological perspective, Ingold suggests, it would typically (in meteorological terms) "bubble up" like a thundercloud and then again like a cloud with considerable fuzziness at the edges. ${ }^{170}$

Currently (in 2014), the San community of Platfontein is in the process of a comprehensive cultural transition to becoming part of an urban society in a semi-arid part of South Africa. Their condition is similar to the processes of cloud formation. It is clearly complex, difficult and somewhat messy for this community to negotiate a route towards a better life in a modern multiracial African democracy. In many respects, it seems as if the community deserves special attention in the formation of a unique cultural cloud that suits their selfdefined social ecological system. The general environment has been unnecessarily harsh on them. It is evident that by attending to the local water and sanitation infrastructure the authorities could make a significant contribution to the wellbeing of a marginalised community.

Acknowledgement: The National Research Foundation in Pretoria, South Africa funded this work. (Grant No. 90310) Any opinion, findings and conclusions or recommendations expressed in this material are those of the author and therefore the NRF does not accept any liability in regard thereto.

\section{References}

Primary sources ${ }^{171}$

Tempelhoff Oral Archive (TOA) 20140711, Interview: H Smit, Director of the Southern African San Institute (SISA), Roodevallei, Pretoria.

TOA20140712 01 ZS, Roodevallei, Pretoria.

TOA20140713 FMM, Roodevallei, Gauteng.

TOA20140815 Interview !Xun and Khwe Community Property Association (CPA), Department of Social Development offices, Platfontein, 15 August 2014.

TOA20140815, Group interview with women at the Nederduitse Gereformeerde Kerk, (NGK), Platfontein, 15 August 2014.

TOA20140816, Interview with members of the Khwe Community Property Association (CPA), Department of Social Development offices, Platfontein, 16 August 2014.

Secondary sources

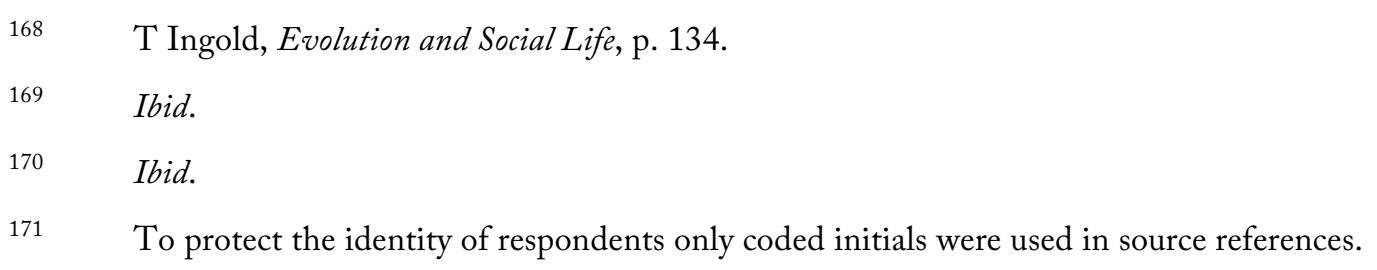

Td, 10(4), December 2014, pp. 52-83. 
Andersson, CJ, Lake Ngami or Explorations and Discovery during Four Years of Wandering in Wilds of South-Western Africa, Facsimile edition by C Struik, Cape Town, 1987, of the second edition, Hurst and Blackett, London, 1856.

Anon., Northern Cape gets San Language Radio, IOL, 19 August 2000, Accessed 7 September 2014, http://goo.gl/x5e0Fw

Anon., San Fear Land Reform Spells Extinction, IOL, 8 July 1999, Accessed 7 September 2014, http://goo.g1/kw8TFK

Baines, T Journal of Residence in Africa 1842-1853, Volume 1, 1842-1849, Edited by RF Kennedy, The Van Riebeeck Society, Cape Town, 1961.

Den Hertog, TN, "Diversity behind Constructed Unity: The Resettlement Process of the !Xun and the Khwe Communities in South Africa", Journal of Contemporary African Studies, 31(3), 2013, pp. 345-360.

Department of Economic and Social Affairs (DESA), Population Division, World Urbanization Prospects: The 2011 Revision, United Nations, New York, 2012.

Department of Human Settlements, Ministerial Task Team Report. Review, Investigation and Evaluation of the National Sanitation Programme - towards Continuous Improvement (July 2012).

Department of Water and Sanitation, Northern Cape, Minutes of meeting on the Homevale Wastewater Treatment Plant: Technical Interventions, DWS, Regional Offices, Kimberley, 12 August 2014.

Google Earth image, of Platfontein, Accessed 16 September 2014.

Halliday, S, The Great Stink of London: Sir Joseph Bazalgate and the Cleansing of the Victorian Metropolis, The History Press, Brimscombe Port, Stroud, 2013.

Hitchcock, RK, "Refugees, Resettlement, Land and Resource Conflicts: The Politics of Identity among!Xun and Khwe San in Northeastern Namibia", African Monographs, 33(2), June 2012, pp. 73-132.

Ingold, T, Evolution and Social Life, Cambridge University Press, Cambridge, 1986.

Khecane, D, Anthrax Outbreak Sends Eight More to Hospital, in IOL, 7 January 2001, Accessed 7 September 2014, http://goo.g1/DCfnbH

King, GFJ, 'Skarreling': A Socio-Environmental History of Household Waste in South Africa (MA, Stellenbosch University, 2014, pp. 14-19.

Le Roux, W and White A (eds), Voices of the San: Living in Southern Africa Today, Kwela Books, Cape Town, 2004.

Mäki, H, Water, Sanitation and Health: The Development of the Environmental Services in Sour South African Cities, 1840-1920, Kehrä Media Inc. Tampere, 2008

Mokoena, M, "Man Drowns in Burst Pipe Hole”, Diamond Fields Advertiser, 7 August 2013, p. 3.

Population Reference Bureau (PRB), World Population Data Sheet, Accessed 31 July 2014, http://goo.gl/yJOoN1 
Robbins, D, On the Bridge of Goodbye: The Story of South Africa's Discarded San Soldiers (Jonathan Ball Publishers, Johannesburg, 2007).

Rowntree, K, "Geography of Drainage Basins: Hydrology, Geomorphology, and Ecosystems Management", in Fox, R and Rowntree, E (eds.), The Geography of South Africa in a Changing World, Oxford University Press. Cape Town, 2000, pp.393-416.

Smith, M, Former San Soldiers still Waiting for Houses, in IOL, 2003.04.18, Accessed 7 September 2014, http://goo.g1/4LXzEp

Smith, C, City Water, City Life: Water and the Infrastructure of Ideas in Urbanising Philadelphia, Boston and Chicago, University of Chicago Press, Ltd., London, 2013.

Smith, M, Long Wait for !Xun and !Khwe Homecoming Ends, in IOL, 20 January 2004, Accessed 7 September 2014, http://goo.gl/no9Gcs

Sapa, Hundreds Wait to Meet Zuma, IOL, 13 November 2008, Accessed 7 September 2014, http://goo.g1/1eK9nu

Sapa, Northern Cape MEC to Visit the San King, in IOL, 12 April 2004, Accessed 2014.09.07 at http://goo.gl/P4fBwP

Sapa, San People Start Voting, in IOL, 14 April 2004, Accessed 7 September 2014, http://goo.gl/zQCqch

Schapera, I, The Khoisan People of South Africa: Bushmen and Hottentots, Routledge \& Kegan Paul, London, 1960.

Seccombe, A, San Trackers Lay Claim to Drakensberg Land, in IOL 13 August 2000, Accessed 7 September 2014, http://goo.g1/rgSkk9

Sedlack, D, Water 4.0: The Past, Present and Future of the World's Most Vital Resource, Yale University Press, New Haven, 2014.

Smith, M, Former San Soldiers still Waiting for Houses, in IOL, 2003.04.18, Accessed 7 September 2014, http://goo.gl/4LXzEp

Smith, M, Long Wait for !Xun and !Khwe Homecoming Ends, in IOL, 20 January 2004, Accessed 7 September 2014, http://goo.g1/no9Gcs

Solomon, S, Water: The Epic Struggle for Wealth, Power and Civilization, Harper-Collins eBooks, New York, 2009.

Thunberg, CP, Travels at the Cape of Good Hope, 1772-1775, Original c. 1795. Edited by VS Forbes. Translation from the Swedish revised by J. and I. Rudner; Contributions to the foreword by I. Rudner and J. Rourke, Van Riebeeck Society, Cape Town, 1986.

Van Wyk, B-E. and Gericke, N. People's Plants: A Guide to the Useful Plants of Southern Africa, Briza Publications, Pretoria, 2007.

Van Zyl, AD, South African Weather and Atmospheric Phenomena, Briza Publications, Pretoria, 2003.

Weidlich, B, San Face Lifestyle Threat, in IOL, 15 October 2007, Accessed 7 September 2014, http://goo.g1/tVnPgL

Wildenboer, N, Platfontein Community Sorry about Abraham the Camel, in IOL, 29 August 2013, Accessed 7 September 2014, http://goo.gl/p7OVbJ 